\title{
Pre-Zechstein structures around the MONA LISA deep seismic lines in the southern Horn Graben area
}

\author{
TANNI ABRAMOVITZ \& HANS THYBO
}

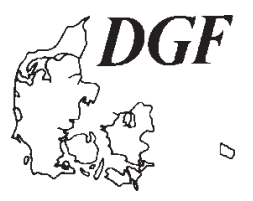

\begin{abstract}
Abramovitz, T. \& Thybo, H.: Pre-Zechstein structures around the MONA LISA deep seismic lines in the southern Horn Graben area. Bulletin of the Geological Society of Denmark, Vol. 45, pp. 99-116. Copenhagen, 1999-01-30. https://doi.org/10.37570/bgsd-1998-45-10
\end{abstract}

Seismic reflection data from the Horn Graben area in the southeastern part of the North Sea, off-shore Denmark, have been interpreted to illustrate the upper crustal structures around the MONA LISA deep seismic lines. The study area comprises the southern Horn Graben area and the eastern part of East North Sea High, where the Caledonian collision suture between Baltica and Eastern Avalonia bends such that the strike direction changes from ESE in the south to NNW in the north. Integrated interpretation of normal-incidence reflection data and wideangle refraction data reveals substantial occurrences of lower and upper Palaeozoic strata in the area, thickest below the Horn Graben. This may indicate that Horn Graben developed as a graben structure during late Palaeozoic in the former Caledonian foredeep. On the northern and eastern parts of the MONA LISA deep seismic reflection lines 1 and 3, the main E- dipping boundary fault of the southern Horn Graben segment appears to be listric at depth with a sub-horizontal detachment at the top of the reflective lower crust. We have mapped the lateral extent of the lower Permian, volcanic Rotliegend reflector in the study area on the basis of seismic lines from the RTD-81 survey. Dipping reflections observed in the sedimentary strata below the Rotliegend reflector are interpreted as Caledonian structures generated by folding and deformation in Lower Palaeozoic Baltica shelf sediments in the Caledonian foreland basin. A sequence of S- and $\mathrm{W}$-dipping reflections above $4 \mathrm{~s}$ twt are interpreted as preserved Caledonian thrusts in the upper crustal frontal part of the SW-dipping Caledonian Deformation Front.

Key words: Horn Graben, seismic reflection and refraction data, MONA LISA, Caledonian structures, Palaeozoic strata, Rotliegend reflector

T. Abramovitz \& H. Thybo, Geological Institute, University of Copenhagen, Øster Voldgade 10, DK-1350 Copenhagen, Denmark. 16 April 1997.

Seismic reflection profiles from the area around the deep seismic MONA LISA lines show structures inherited from Caledonian collisional processes, Late Palaeozoic extension and magmatism, and Mesozoic graben formation (MONA LISA Working Group 1997) (Fig. 1). We present examples of Caledonian structures in the sediments between the Rotliegend and basement reflectors in the Horn Graben accommodation zone area, the southern Horn Graben and in small Palaeozoic half-grabens in the basement of the East North Sea High. Dipping reflections from nearbasement levels are interpreted as Caledonian thrust and nappe structures. We demonstrate that the front of such structures may be consistently mapped as the upper part of a curved, SW-dipping, crust-cutting reflection band.
The effect of the late-Variscan orogeny on basin formation around Denmark has been a subject of much debate. Vejbæk (1990) considered the Horn Graben as a mainly Mesozoic structure. Here, we show images that suggest a main component of Late Carboniferous to Early Permian extension for the graben formation, associated with volcanic activity and possibly magmatic underplating.

Conventional seismic normal-incidence reflection data recorded to $7 \mathrm{sec}$ two-way-traveltime (s twt) from the RTD-81 and NP85N surveys illustrates the nearsurface sedimentary structures in the Horn Graben area where the two deep seismic $26 \mathrm{~s}$ twt MONA LISA profiles 1 and 3 intersect (Fig. 2). The network of $7 \mathrm{~s}$ twt sections allows correlation of the near-surface sedimentary sequences and helps to constrain the lateral 


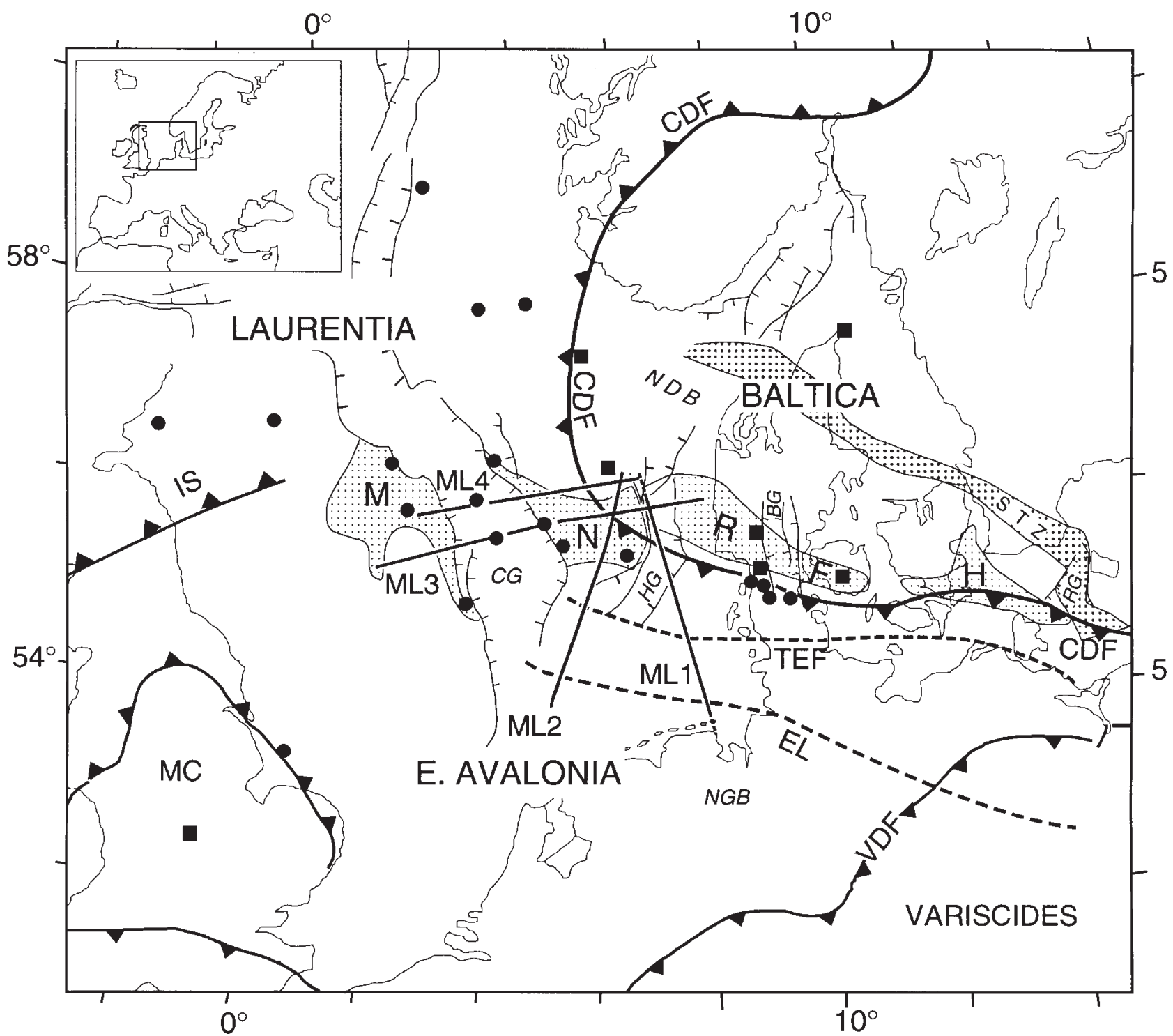

Fig. 1. Tectonic map of the North Sea region showing the location of the MONA LISA profiles (ML1-4). The study area around Horn Graben is shown by the black square. Basement ages at boreholes are indicated: Precambrian age ( $880-825$ $\mathrm{Ma})$ by squares and Caledonian age (450-415 Ma) by circles. The present day position of the three crustal plates (Baltica, Laurentia and E. Avalonia) involved in the Caledonian collision are indicated. Abbreviations; CDF: Caledonian Deformation Front; TEF: Trans-European Fault; EL: Elbe Lineament; IS: Iapetus Suture; MNRFH: Mid North Sea-Ringkøbing Fyn High; HG: Horn Graben; CG: Central Graben; MC: Midlands microcraton; VDF: Variscan Deformation Front; NGB: North German Basin; NDB: Norwegian Danish Basin; STZ: Sorgenfrei Tornquist Zone; RG: Rønne Graben. (Modified after MONA LISA Working Group 1997).

extent of the variations in structures observed on the MONA LISA profiles. The main emphasis will be on the sedimentary sequence of the Caledonian foredeep which is now preserved between the Rotliegend and basement reflectors, and the possible connection with deeper crustal structures will also be discussed.

\section{Geological setting}

During the end of the Ordovician and Early Silurian, the present day North Sea was the scene of the Caledonian triple plate collision between two major continents, Laurentia and Baltica, and a Gondwana-derived micro-continent Eastern Avalonia (E. Avalonia). Prior to collision the Tornquist Sea, a narrow ocean, separated Baltica and E. Avalonia (Cocks \& Fortey 1982). Today, the most compelling evidence for the existence of the Caledonian orogen are the contrast- 
Fig. 2. Location map of the seismic lines from the NP85Nsurvey in the Horn Graben area and the position of the deep seismic MONA LISA profiles. The profiles discussed in the text (Figs 4-10) are marked by thick black lines. Abbreviations: n-HG: northern Horn Graben segment; a-HG: Horn Graben accommodation zone; s-HG: southern Horn Graben segment; ENSH: East North Sea High; WSB: West Schleswig Block. Shaded signature illustrates areas on East North Sea High where the Rotliegend reflector is absent. Also shown are the location of the S-1 and $\mathrm{R}-1$ wells and the main faults of Horn Graben.

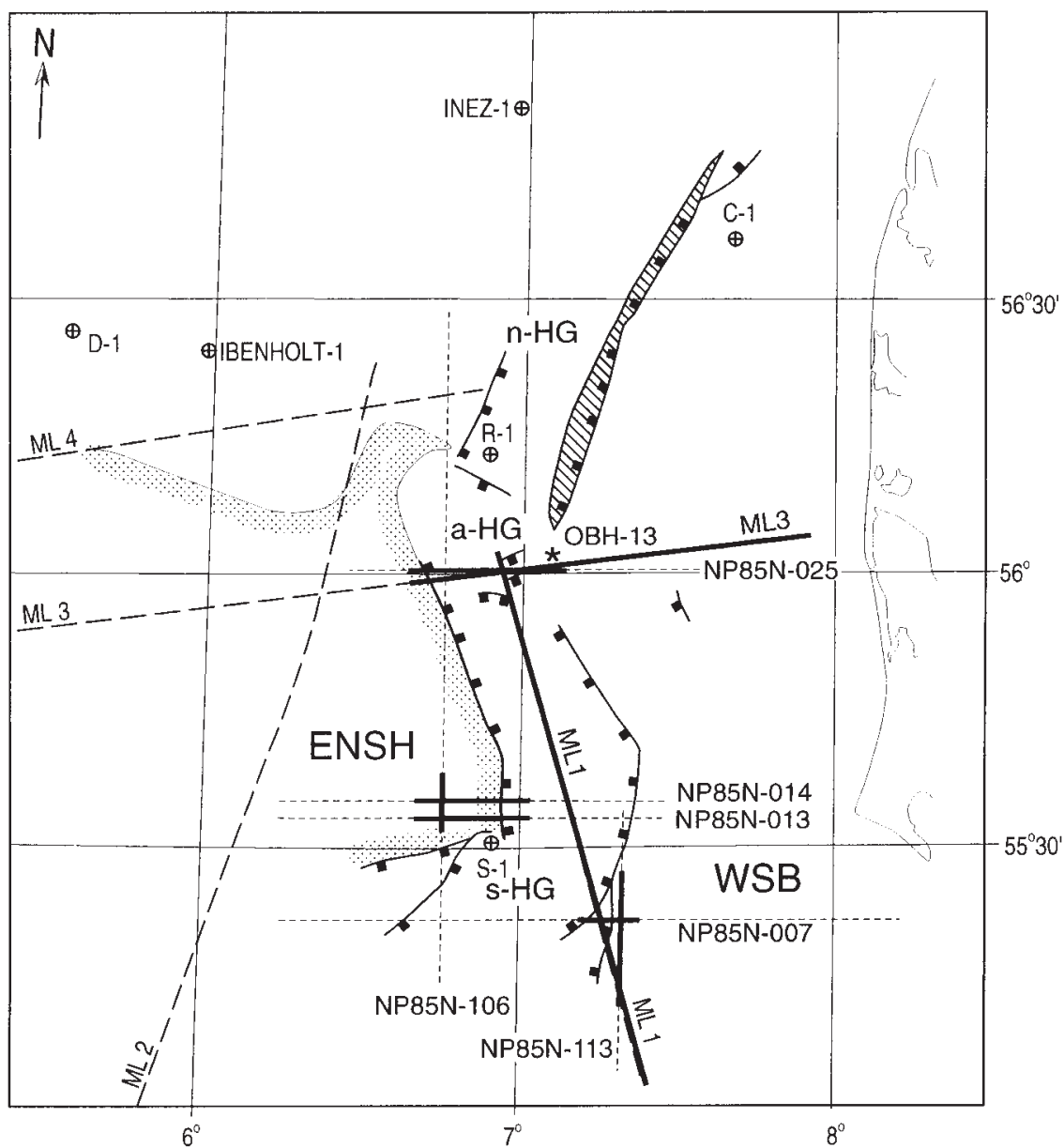

crust during the northward closure of the Tornquist Sea. Integrated interpretation and modelling of the MONA LISA normal-incidence and wide-angle data from the two N-S striking profiles show that these Sdipping crustal reflections coincides with a suture zone separating a three-layered Baltica type crust of high average velocities to the north from a two-layered $\mathrm{E}$. Avalonia type crust of low average velocities to the south (Abramovitz et al. 1998; Abramovitz \& Thybo in review).

The Mid North Sea-Ringkøbing Fyn High is a roughly E-W striking basement high which extends for $\sim 800 \mathrm{~km}$ across the North Sea and onshore Denmark to the Baltic Sea (Sorgenfrei \& Buch 1964; EUGENO-S Working Group 1988; Cartwright 1990; Ziegler 1990). The basement high consists of individual blocks which are divided by N-S striking grabens, i.e. the Central Graben, Horn Graben, the onshore Brande Graben and Rønne Graben further to the east. The basement high came into existence during regional tectonic activity in Late Carboniferous to Early Permian times (Cartwright 1990). The Mid North Sea-Ringkøbing Fyn High acted as a barrier 


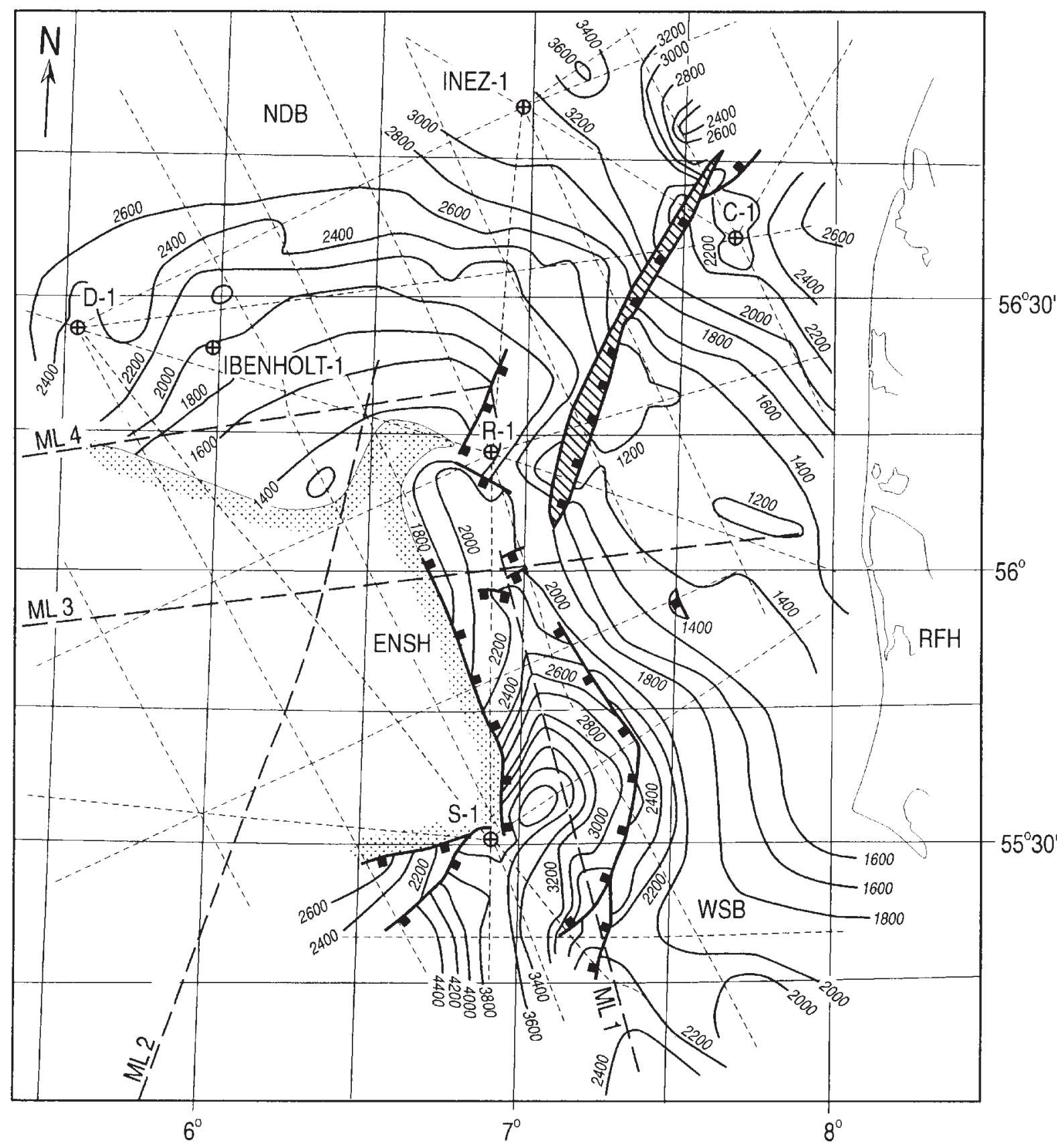

Fig. 3. Map of the two-way traveltime to the Rotliegend reflector based on interpretation of seismic lines from the RTD81 survey (thin stippled lines) and the MONA LISA seismic lines (marked by ML1-4). The map illustrates the division of Horn Graben into a southern and northern segment. The Rotliegend reflector is absent on seismic lines from the East North Sea High as shown by the shaded signature. Contour interval is $200 \mathrm{~ms}$.

between the northern and southern North Sea basins during the Permian; i.e. the Norwegian-Danish Basin (NDB) and the North-German Basin (NGB). The basement block west of Horn Graben will be referred to as the East North Sea High.

The tectonic evolution of the N-S striking Horn
Graben of the southeastern North Sea has been discussed by several authors (Best et al. 1983; Vejbæk 1990; Clausen \& Korstgård 1993; Clausen \& Korstgård 1994). Horn Graben is composed of a northern and a southern segment, and the two segments have the form of oppositely verging half-grabens which are 
divided by an accommodation zone around the R-1 well. The boundary faults are $\mathrm{W}$-dipping in the northern and E-dipping in the southern segment. This paper concentrates on structures in the accommodation zone area and the southern segment. The E-dipping, main boundary fault separates the southern half-graben from the basement high of the East North Sea High to the west. The main graben fill consists of an up-to $3 \mathrm{~s}$ twt thick Triassic sequence which is underlain by Zechstein deposits in the southern segment. The preZechstein basal fill of the graben is considered to be of Devonian, Carboniferous and Rotliegend age (Vejbæk 1990). Lower Permian Rotliegend volcanic rocks have been encountered in borehole cores from the R-1, D-1 and C-1 wells in the northern part of the Horn Graben area. The Rotliegend deposits in the Danish region consist of volcanic and associated sedimentary rocks. The composition of the Rotliegend volcanics in the Horn Graben area ranges from a bimodal alkaline-transitional basaltic suite to a rhyoliterhyodacite suite that are genetically related by fractional crystallization (Aghabawa 1993). K-Ar age determination methods yield ages of 274-237 Ma for the volcanics in the borehole cores.

The North German Basin, south of the Mid North Sea-Ringk øbing Fyn High, was initiated during Devonian basin formation probably as a result of postorogenic gravitational collapse of the North German Caledonides. The Caledonian structures may have been reactivated during the Late Carboniferous to
Early Permian Variscan wrench tectonics where crustal thinning and associated magmatic activity formed the southern Permian basin, which now contains up-to 10 $\mathrm{km}$ sediments of Devonian to Cenozoic age (Aichroth et al. 1992; Brink et al. 1992). The northern part of the North German Basin is the West Schleswig Block, which forms the southern slope of the Mid North SeaRingkøbing Fyn High (Best et al. 1983).

\section{Seismic images}

The most prominent marker reflection of the Horn Graben area is the Rotliegend reflector. Its strong seismic signature is caused by the impedance contrast between the Lower Permian volcanics and sediments as encountered in borehole cores from the R-1, D-1 and C-1 wells. The Rotliegend reflector outlines a major unconformity between pre-rift and syn-rift deposits in the Horn Graben area. The unconformity is imaged by upward truncation of dipping reflections from the pre-rift deposits.

We have mapped the lateral extent of the Rotliegend reflector in the study area on the basis of interpretation of seismic lines from the RTD-81 survey (Fig. 3). This map is different from the top PreZechstein map published by GEUS (Vejbæk \& Britze 1994; Vejbæk 1997) because the GEUS-map illustrates the depth to the top Pre-Zechstein surface whereas our

\section{NP85N-025}

W

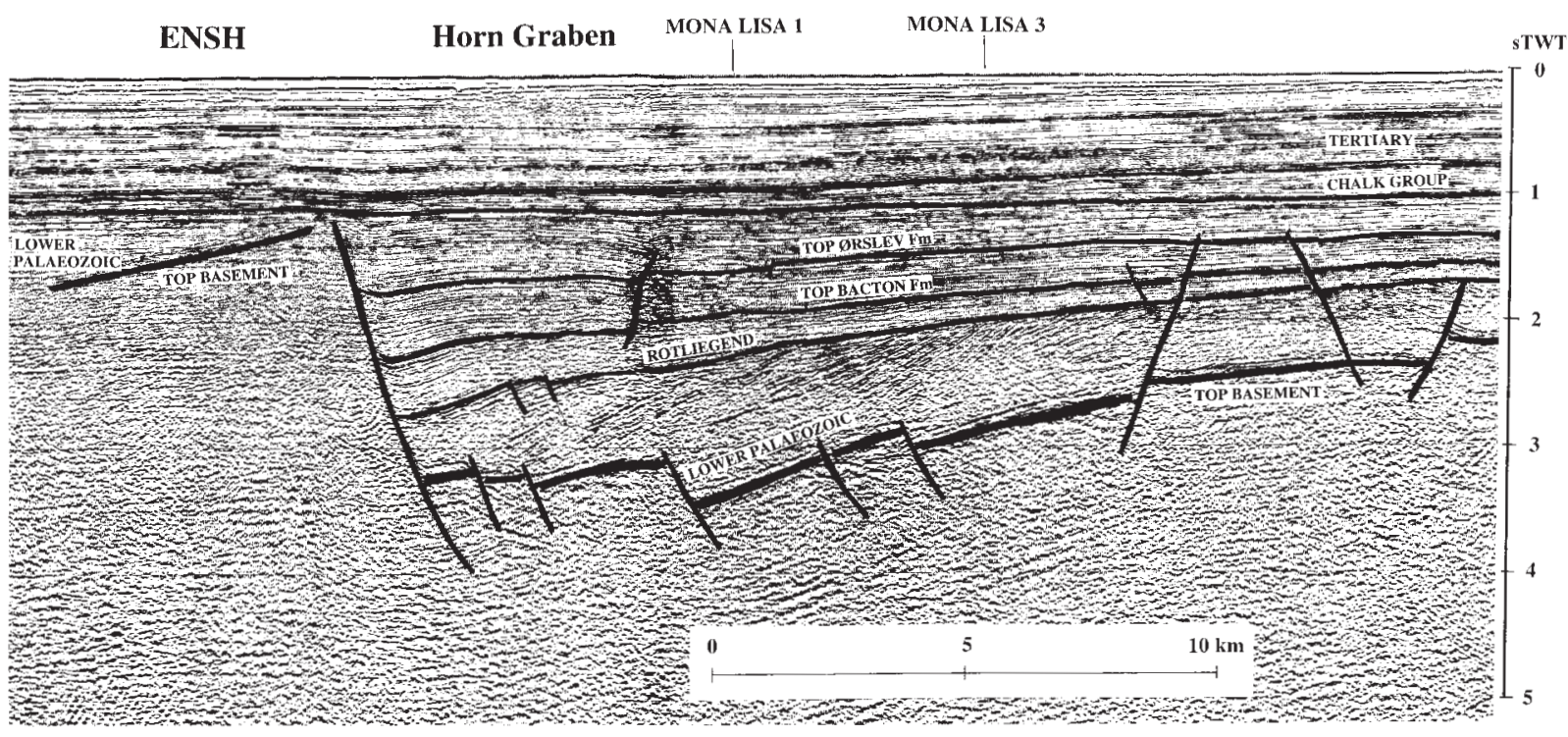

Fig. 4. The unconformity of the Rotliegend reflector imaged by the truncation of dipping reflectors in the pre-rift deposits on the time migrated, E-W striking NP85N-025 profile from the Horn Graben accommodation zone across the western boundary fault. (Tertiary = Cenozoic). 
ENE

MONA LISA Line 3

WSW

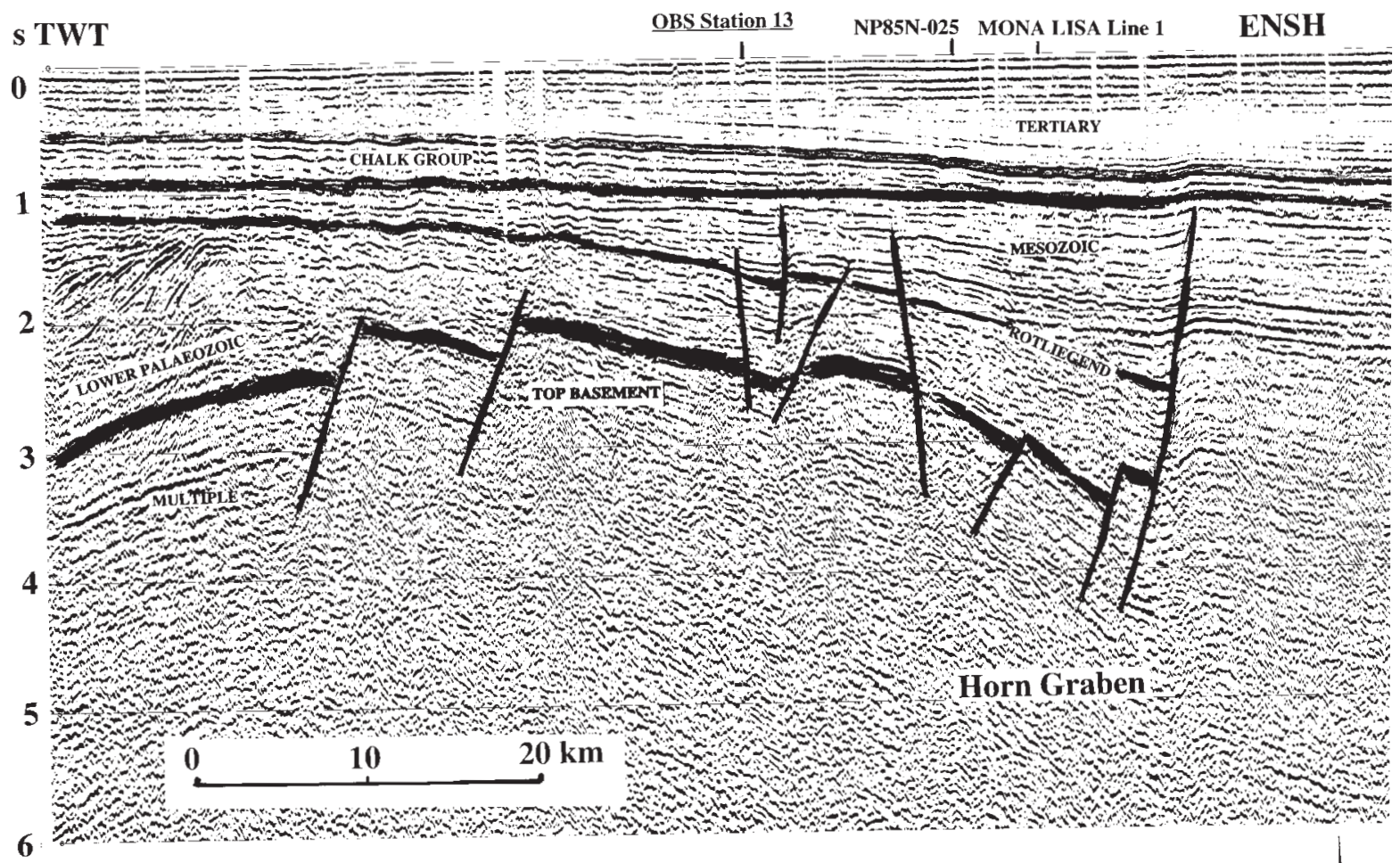

Fig. 5. The unconformity of the Rotliegend reflector illustrated on the eastern part of the E-W striking, unmigrated MONA LISA profile 3 from the Horn Graben accommodation zone. (Tertiary = Cenozoic).

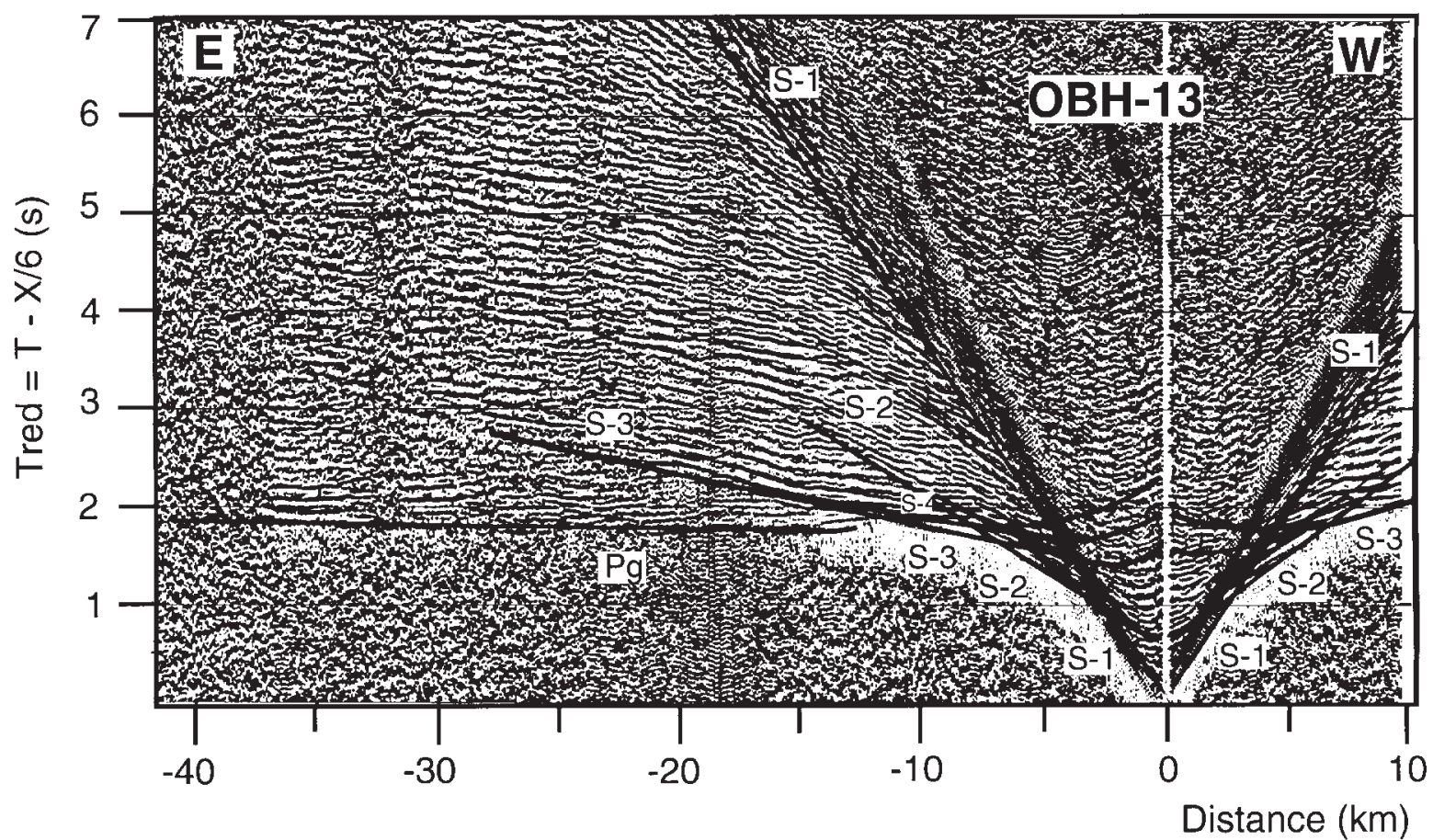

Fig. 6. Interpretation of sediment and basement velocity structure along MONA LISA profile 3 in the Horn Graben area. A) Wide-angle section from ocean bottom hydrophone OBH-13 which was located $\sim 25 \mathrm{~km}$ east of the main Horn Graben boundary fault in the accommodation zone (reduction velocity $6 \mathrm{~km} / \mathrm{s}$ ). The seismic section is superimposed by calculated traveltime branches from the velocity model. Abbreviations for the refracted phases: S-1: Cenozoic, S-2: Mesozoic, 
b)

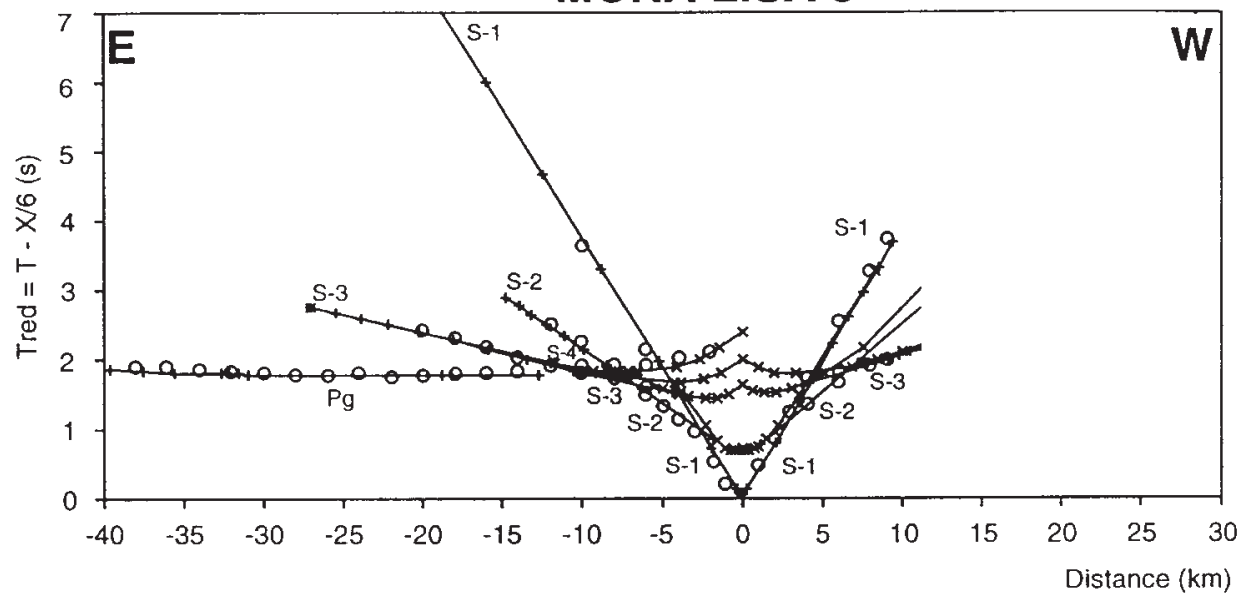

c)

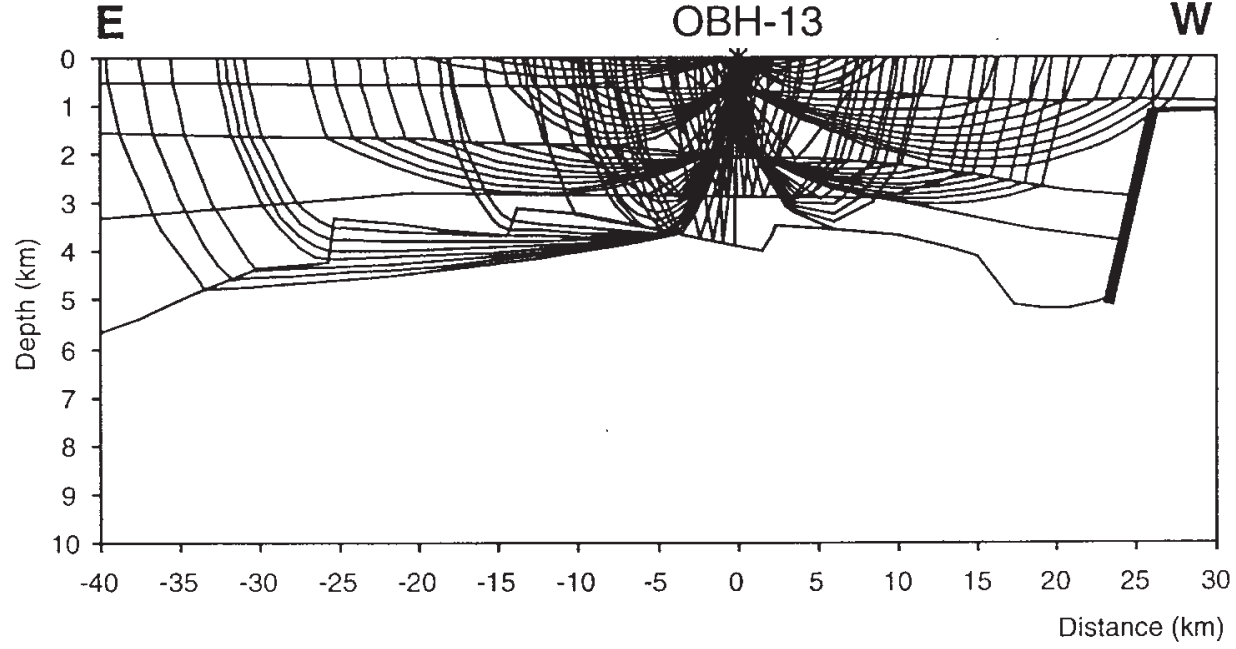

d)
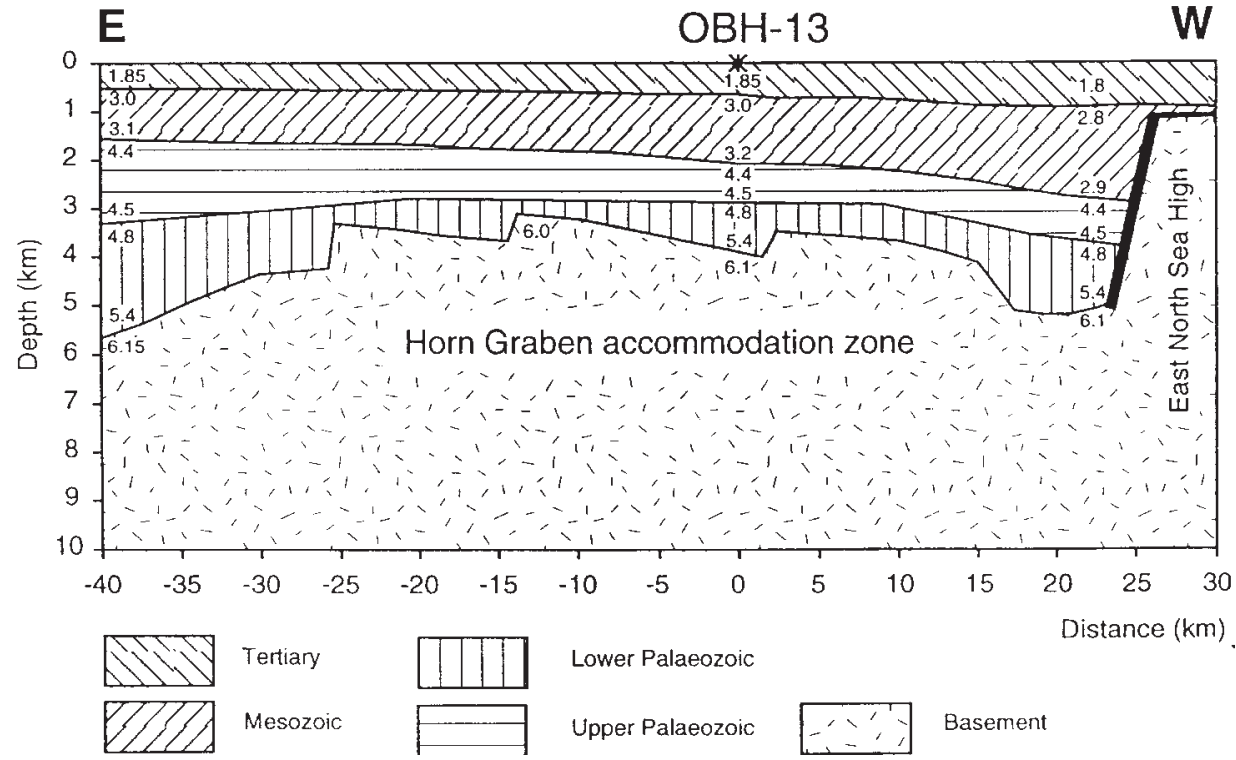

S-3: U. Palaeozoic, S-4: L. Palaeozoic, Pg: crystalline basement. B) Observed (open circles) and calculated (crosses) traveltimes from the velocity model. C) Ray coverage of the velocity model. D) The velocity model showing a Cenozoic layer of P-wave velocities 1.75-1.86 km/s; a Mesozoic layer of velocities $2.85-3.2 \mathrm{~km} / \mathrm{s}$; an upper Palaeozoic layer of velocities $4.4-4.5 \mathrm{~km} / \mathrm{s}$ and a lower Palaeozoic layer of velocities $4.8-5.4 \mathrm{~km} / \mathrm{s}$. The crystalline basement of the upper crust has velocities of $6.0-6.15 \mathrm{~km} / \mathrm{s}$. There is no reverse coverage of the model. Depths to the model interfaces are constrained by the twt from the ML3 normal-incidence section. (Tertiary = Cenozoic). 


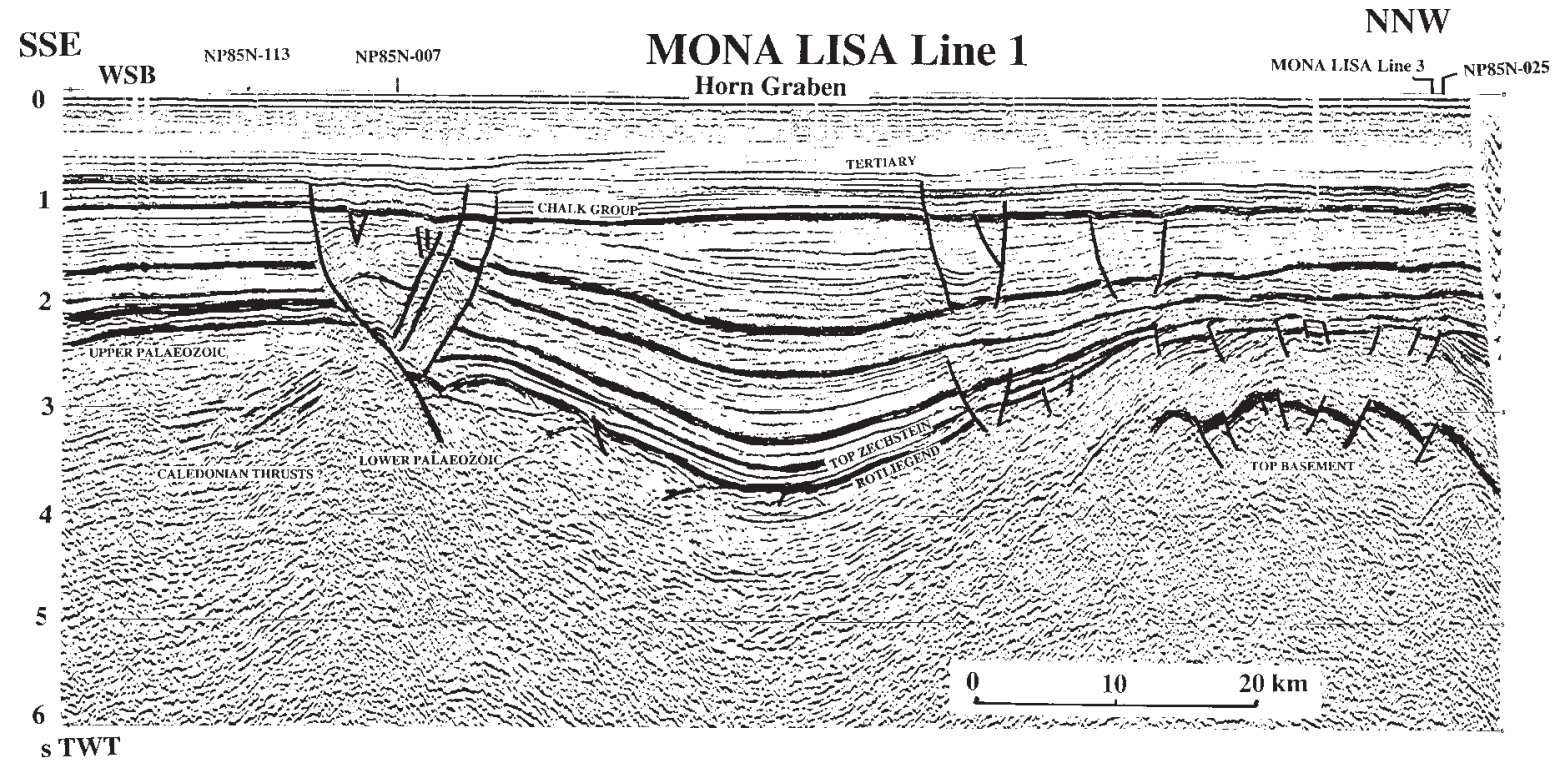

Fig. 7. Seismic structures in the strike direction of the Horn Graben along the unmigrated, N-S directed MONA LISA profile 1. The top basement reflection is pronounced in the northern part of the section (Baltica part). S-dipping reflections in the southern part of the section near the Horn Graben-West Schleswig Block transition zone are interpreted as Caledonian thrusts in the upper frontal part of the Caledonian Deformation Front. (Tertiary = Cenozoic).

map illustrates the depth to and the occurrence of the Rotliegend reflector. Both in the northern and southern Horn Graben segments, the Rotliegend reflector is locally overlain by Zechstein deposits (Vejbæk 1990, 1997). However, the Rotliegend reflector can also be recognized in areas where Zechstein deposits are absent (Figs 4-5). The contoured two-way traveltimeisolines varies from $1200 \mathrm{~ms}$ to $4400 \mathrm{~ms}$. The Rotliegend reflector is absent on the East North Sea High, west of Horn Graben, where the pre-Zechstein deposits are present (Vejbæk \& Britze 1994) in small downfaulted half-grabens overlain by a Jurassic sequence. This absence indicates that the Rotliegend rocks have been removed by erosion during uplift of the basement high.

The top basement is characterised by a strong, continuous double reflection (Figs 4-5). Such reflections from the top basement have only been observed from Baltica crust north and east of the Caledonian Deformation Front in the study area and not in the southern deeper parts of Horn Graben. The Precambrian crystalline basement has been reached by the Ibenholt-1 well, north of East North Sea High in the southern part of the Danish-Norwegian Basin. Rocks from this well provide a K-Ar age of 844-781 My \pm 21 My for the basement (Phillips Petroleum Company 1987). The seismic signature of the basement reflector in the Horn Graben area resembles the reflectivity pattern of the top of the Hardeberg sandstone as observed on the seismic line K 83-005 from Kattegat around the Terne1 well (Fig. 5 in Michelsen \& Nielsen 1993). This sandstone is equivalent to the marine Balka sandstone and a lower Cambrian sandstone found in the Slagelse1 well in onshore Denmark (Poulsen 1969). Without well support, we suggest that the strong double basement reflection in the Horn Graben area corresponds to an offshore equivalent of the top of lower Cambrian sandstones.

\section{The Horn Graben accommodation zone}

In the Horn Graben accommodation zone between the northern and southern segments two obliquely intersecting profiles illustrate the structures in the pre-rift sequence between the Rotliegend and basement reflectors: the eastern part of the E-W striking, unmigrated MONA LISA profile 3 (ML3) (Fig. 5) and profile NP85N-025, which is an E-W striking time migrated $7 \mathrm{~s}$ twt section (Fig. 4). The seismic marker horizons have all been tied to the nearby R-1 well further north. Both profiles image the structural contact along the E-dipping main boundary fault between the basement of the East North Sea High in the footwall block and the deeper parts of Horn Graben in the hanging wall.

The main fault offsets the basement reflection with a throw of $\sim 2.1 \mathrm{~s}$ twt. The top basement reflector is outlined by minor fault-bounded blocks with E-dipping fault planes and W-rotated basement surfaces in the deeper parts (Fig. 5). Between the basement and Rotliegend reflections a sequence of reflections are observed. These reflections are W-dipping to sub-horizontal at $1.9-3.1 \mathrm{~s}$ on NP85N-025 and E-dipping at 


\section{MONA LISA 1 NP85N-113}

\section{Horn Graben}

WSB

sTWT

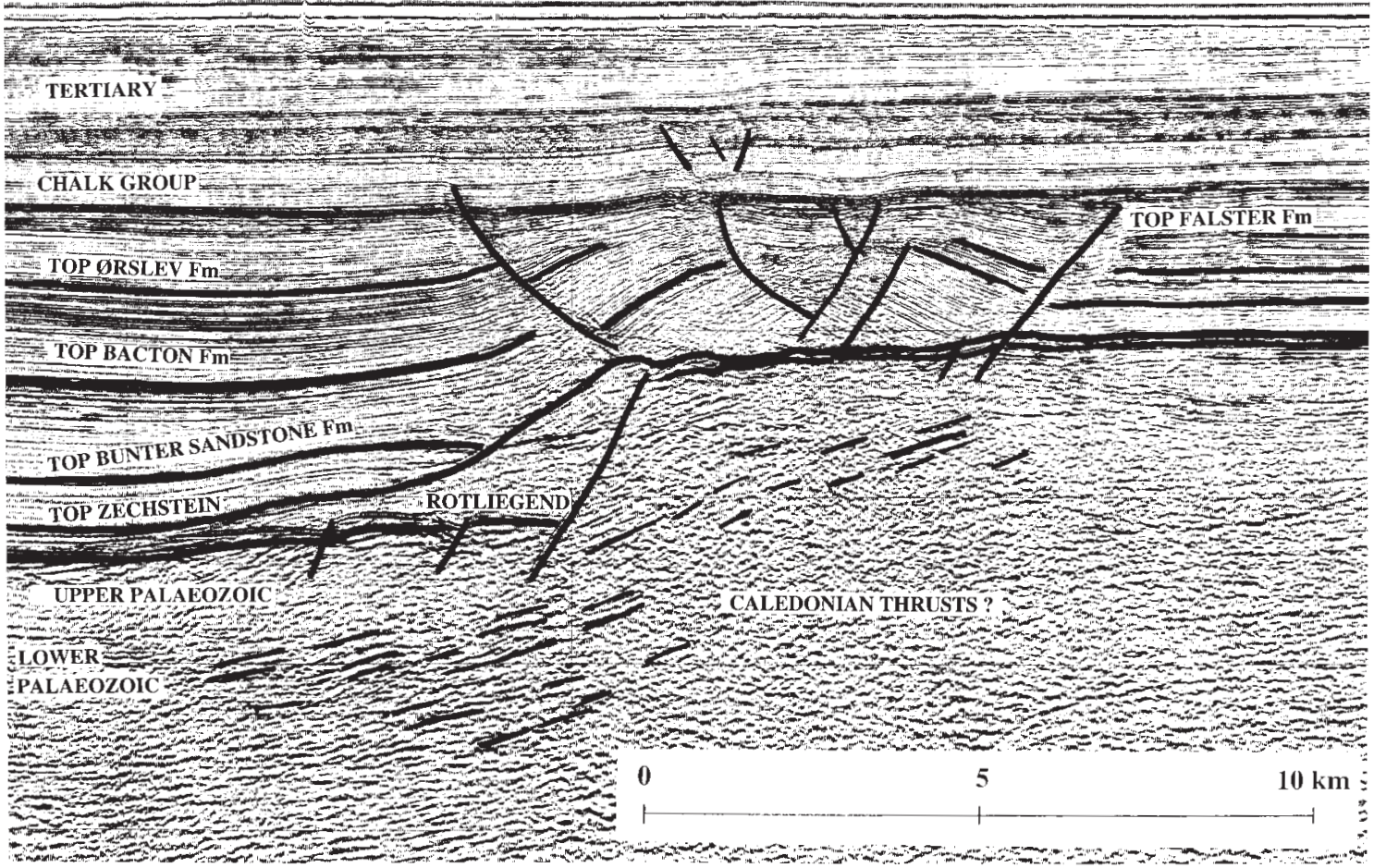

MONA LISA 1

WSB

NP85N-1007

Horn Graben : IW

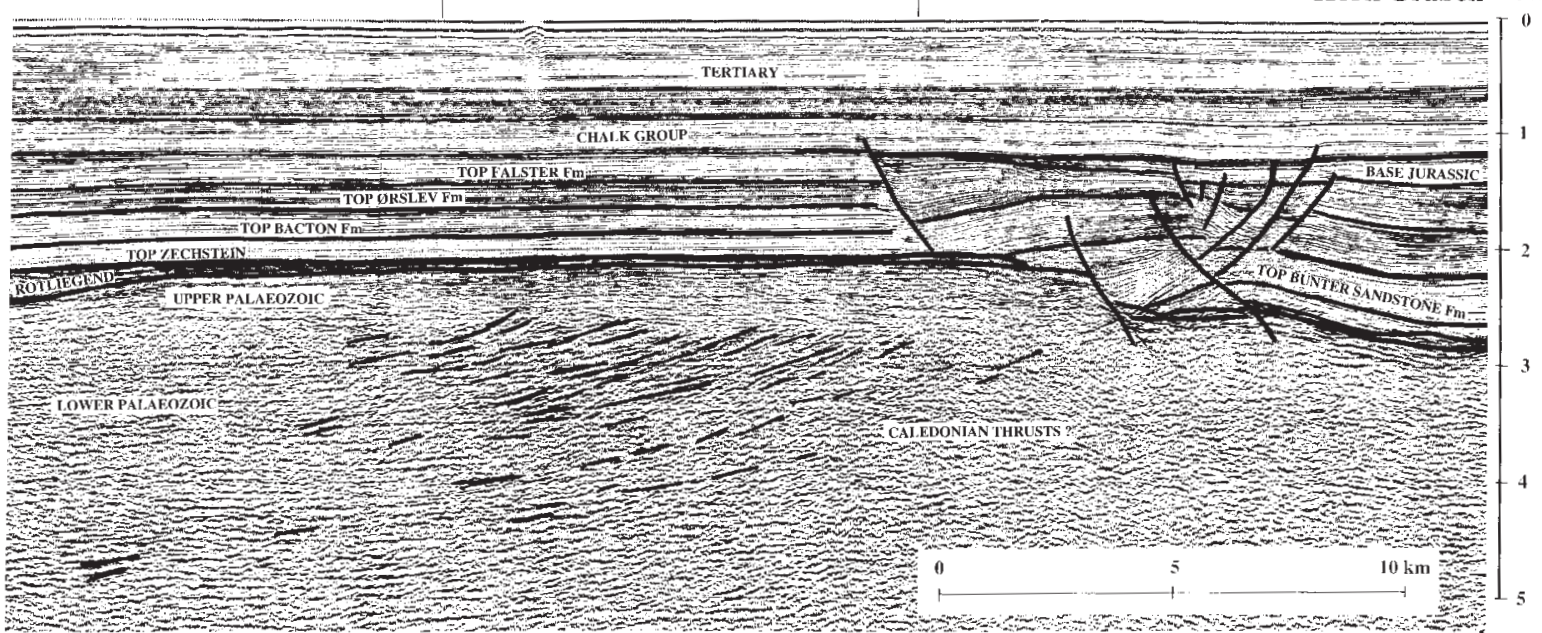

\section{B}

Fig. 8. Examples of Caledonian structures on seismic sections from the Horn Graben-West Schleswig Block transition zone. S- and W-dipping reflections are interpreted as Caledonian thrusts identical to those on ML1 (Tertiary = Cenozoic).

A) The time migrated, E-W striking NP85N-007 profile. B) The time migrated, N-S striking NP85N-113 profile. 
1.3-2.2 s on the eastern end of ML3. The thickness of the pre-rift deposits varies from 0.6 to $1.8 \mathrm{~s} \mathrm{twt}$ in the two profiles. A small W-dipping half-graben with down-faulted, presumably, lower Palaeozoic strata is observed on NP85N-025 in the East North Sea High, just west of the E-dipping boundary fault (Fig. 4). This structure cannot be identified on ML3, although indicated, due to the high noise level and multiples from the sub-horizontal post-rift sediments of the Chalk Group.

During the first phase of the MONA LISA project in 1993, an ocean bottom hydrophone (OBH) recorded the airgun shots at a position $\sim 25 \mathrm{~km}$ east of the main boundary fault in the Horn Graben accommodation zone, near the intersection between ML3 and NP85N025. Modelling of refracted and reflected upper crustal seismic phases, as interpreted from the wide- angle section, provides information about the velocity depth structure of the sedimentary layers. Refracted phases from four different sedimentary layers (S-1 to S-4) and the refracted phase from the top of the basement $(\mathrm{Pg})$ have been modelled in the velocity model (Fig. 6). There is no reverse coverage of the model and the depths to the model interfaces are constrained by the reflections in the ML3 normal-incidence reflection section. The velocity model shows a Cenozoic layer of P-wave velocities $1.75-1.86 \mathrm{~km} / \mathrm{s}$; a Mesozoic layer (the Triassic to Chalk Group strata) of velocities $2.85-3.2 \mathrm{~km} / \mathrm{s}$ and two Palaeozoic layers. The twt to the base of the Mesozoic layer corresponds to the observed Rotliegend reflection on the ML3 normalincidence section. Velocities are $4.4-4.5 \mathrm{~km} / \mathrm{s}$ for the upper Palaeozoic layer; $4.8-5.4 \mathrm{~km} / \mathrm{s}$ for the lower Palaeozoic layer and $6.0-6.15 \mathrm{~km} / \mathrm{s}$ for the crystalline basement. The basement topography as determined from the wide-angle section corresponds to the basement reflection interpreted on ML3.

\section{Shallow structure of Horn Graben}

The shallow structure of the southern Horn Graben segment can be seen on the NNW-SSE striking MONA LISA profile 1 (ML1) which is parallel to the strike direction (Fig. 7). The northern end of ML1 intersects with ML3 and profile NP85N-025 in the accommodation zone. The unmigrated final stacked section of the upper $6 \mathrm{~s}$ twt of ML1 images the transition from Baltica to Avalonia crust at the southern edge of Horn Graben on the West Schleswig Block. The top basement reflector is recognised over a horizontal distance of $\sim 25 \mathrm{~km}$ in Baltica crust at the northern end of the profile. The basement reflection disappears below Horn Graben, probably because of multiples from the overlying thick sedimentary sequence of the graben and strong attenuation of the seismic signal. S- and N dipping reflections from 2.2 to $2.6 \mathrm{~s}$ twt from the upper part of the pre-rift deposits are unconformably truncated by the Rotliegend reflections in the north- ern part of ML1 (Fig. 7). The lower parts of the prerift deposits appear transparent. The $\mathrm{N}$-dipping reflections correlate with $\mathrm{W}$-dipping reflections on profile NP85N-025 and the S-dipping reflections continue beneath the main graben. The pre-rift deposits are preserved as an up-to $1 \mathrm{~s}$ twt thick sequence between the Rotliegend and top basement reflectors at the intersection between MONA LISA profiles 1 and 3. The average thickness of the pre-rift deposits appears to increase southwards from the accommodation zone $(0.7-1.3 \mathrm{~s}$ twt $)$ but no estimates can be made from beneath the graben due to lack of basement reflections.

The Rotliegend reflector is at 2.2-2.4 s twt in the north and south, and $3.8 \mathrm{~s}$ in the central parts of Horn Graben (Fig. 7). In the deep parts of the graben, it is overlain by Zechstein deposits which onlap the Rotliegend reflector to the north. The Triassic syn-rift sediments are up-to $2.4 \mathrm{~s}$ twt thick in the central part of the graben and thins to the north and south (1.1$1.0 \mathrm{~s}$ twt). A N-dipping fault zone on ML1 marks the transition from Horn Graben to West Schleswig Block. The main fault activity in the Horn Graben-West Schleswig Block transition zone took place during deposition of the thick lower Triassic sequences of the Bunter Sandstone Formation and Bacton Group. The syn-rift sediments are unconformably overlain by the upper Cretaceous (0.2-0.3 s twt) and the Cenozoic (0.9-0.8 s twt) post-rift sequences.

Below the Horn Graben-West Schleswig Block transition zone, a sequence of strong, S-dipping reflections are observed from 2.6 to $3.5 \mathrm{~s}$ twt in the lower part of the pre-rift deposits. These reflections have stronger amplitude than the dipping reflections seen on the northern part of ML1. The S-dipping reflections occur in a region without observable basement reflections. They are overlain by a weakly reflective unit dominated by sub-horizontal reflections, which we interpret as the upper part of the pre-rift deposits. Furthermore, on the $26 \mathrm{~s}$ twt deep normal- incidence reflection section of ML1, these S-dipping reflections continue through the entire crust from 3-11 s twt over a horizontal distance of $\sim 70 \mathrm{~km}$ and terminate at the reflection seismic Moho (MONA LISA Working Group 1997, Abramovitz et al. 1998). In agreement with Vejbæk (1990), we interpret these S-dipping reflections at the southern Horn Graben edge as images of preserved Caledonian thrusts in the upper frontal part (i.e. in the upper crust) of the deep-seated Caledonian Deformation Front.

The S-dipping reflections near the Horn GrabenWest Schleswig Block transition zone correlate directly with similar S- and W- dipping reflections observed in the same time interval $(2.6-3.5 \mathrm{~s}$ twt $)$ on two conventional $7 \mathrm{~s}$ twt sections, the E-W striking NP85N-007 profile and the N-S striking NP85N-113 profile (Fig. 8). The top basement reflector is not identified beneath the graben or beneath the platform on the NP85N-007 profile (Fig. 8a). Strong W- dipping 
reflections from the pre-rift deposits and the upper crystalline crust are observed in both the hanging wall and footwall block of the Horn Graben-West Schleswig Block transition zone. W-dipping reflections in the footwall block at 2.5 to $3.4 \mathrm{~s} \mathrm{twt} \mathrm{correlate} \mathrm{directly}$ with the strong S- dipping reflections on ML1 at the point of intersection, thereby verifying the SW-dip of the reflections. The $\mathrm{W}$-dipping reflections continue below the graben floor in the hanging wall block at 3.6 to $4.7 \mathrm{~s}$ twt. This lower reflective unit is overlain by a weakly reflective unit of sub-horizontal reflections similar to what is observed on ML1 above the Sdipping reflections. On the NP85N-113 profile (Fig. $8 b)$, a sequence of S-dipping reflections between 2.5 and $4 \mathrm{~s}$ twt in the pre-rift deposits extends for a horizontal distance of $16 \mathrm{~km}$ beneath the West Schleswig Block, and they correlate with similar reflections on NP85N-007 and ML1. Similar S- to W-dipping reflections are identified on other profiles and together their N- to E-ward termination identifies a SW-curving feature in the area which we interpret as the upper frontal part of the Caledonian Deformation Front.

We consider the lower unit of the pre-rift deposits with the W- and S-dipping reflectors to be of early Palaeozoic age (Cambrian-Silurian) and the upper, more transparent unit to be of late Palaeozoic age (Devonian- Carboniferous). The velocity model by Abramovitz et al. (1998) of the crustal structure along ML1 shows evidence for an upper Palaeozoic layer with P-wave velocities of $3.9-4.7 \mathrm{~km} / \mathrm{s}$ and a lower Palaeozoic layer of $4.7-5.6 \mathrm{~km} / \mathrm{s}$, matching velocities on ML3 (Fig. 6). The velocities of the lower Palaeozoic layer are similar to values reported from the Skagerrak Graben, where they are interpreted as Cambrian and Silurian deposits (Lie et al. 1993). In the Horn Graben accommodation zone area, the thickness of the upper Palaeozoic layer is $1.3 \mathrm{~km}$ and the lower Palaeozoic layer is $1.4-2.0 \mathrm{~km}$ thick. The thickness of the lower Palaeozoic layer increases to $2.5 \mathrm{~km}$ below the deep parts of the graben.

The NP85N-007 and NP85N-113 profiles image the Horn Graben-West Schleswig Block transition zone as a WNW-dipping boundary fault (Fig. 8). On these two profiles, the depth to the Rotliegend reflector varies from 2.1-2.2 s twt on West Schleswig Block in the south-east to $3.1-3.3 \mathrm{~s}$ twt beneath the graben floor, where it is cut by minor W-dipping faults. The overlying Zechstein deposits show lateral thickness variations from $0.1-0.2 \mathrm{~s} \mathrm{twt}$ in the west and southeast to $0.8 \mathrm{~s}$ twt in a salt wedge near the NW-dipping fault plane (Fig. 8a). The salt wedge is less pronounced on the N-S striking profiles (Figs 7 and 8b). Halokinesis led to collapse of the overlying sediments and a negative flower structure with several internal synthetic and antithetic faults (Fig. 8). Similarly, the Triassic syn-rift deposits display lateral thickness variation from $1.7-2.0 \mathrm{~s}$ twt in the graben to $0.8-1.0 \mathrm{~s}$ twt to the south-east. The post-rift sequence consists of the $\sim 0.3 \mathrm{~s}$ twt thick Chalk Group which truncates the up- per Triassic reflections at an unconformity between Upper Triassic and Lower Cretaceous. The Cenozoic strata have a fairly uniform thickness of $0.9-1.0 \mathrm{~s} \mathrm{twt}$ in the area.

\section{Deep structure of Horn Graben}

The deep crustal structure of the Horn Graben accommodation zone area is illustrated by line drawings of crustal reflectivity along the northern and eastern parts of the two deep normal-incidence reflection MONA LISA profiles 1 and 3 (MONA LISA Working Group 1997) (Fig. 9).

The upper crust is transparent beneath the basement reflections in the northern part of ML1 (Fig. 9a). A middle crustal reflective band at 5.8-8 s twt shows a dome shape of dipping to sub-horizontal reflections. Two lower crustal, reflective lenses of $\sim 50$ and $~ 30$ $\mathrm{km}$ width at 8.2-8.6 s twt are symmetrically distributed around the Horn Graben. Their base coincides with the termination of crustal reflectivity, i.e. the reflection seismic Moho. The internal parts of both lenses consist of dense bands of dipping reflections which encompass transparent zones. A narrow subhorizontal band at 10.6-10.7 s delineates the base of crustal reflectivity below the Horn Graben.

On the eastern part of ML3, the upper and middle crust is transparent beneath the basement reflections (Fig. 9b). Between 7.7 to $8.6 \mathrm{~s}$ twt at middle and lower crustal depths a gently E-dipping reflective band is observed which merges with the reflective lower crust to the east. The base of lower crustal reflectivity is at 10.6 to $11.5 \mathrm{~s}$ twt in the easternmost part of ML3. A strong, high amplitude, coherent double Moho reflection is observed below the graben near the boundary fault. West of Horn Graben, the upper crustal reflectivity in the East North Sea High is dominated by a band of W-dipping reflections from 2.7 to $6.7 \mathrm{~s} \mathrm{twt} \mathrm{in}$ the otherwise transparent upper and middle crust. We interpret these reflections as images of preserved Caledonian thrusts in the upper frontal part of the SWdipping Caledonian Deformation Front. The lower crust of East North Sea High is reflective between 7.4 and $11.5 \mathrm{~s}$ twt. The base of crustal reflectivity is at 10.6 to $11.8 \mathrm{~s}$ twt (Fig. $9 \mathrm{~b}$ ).

The deep crustal structures on ML1 and ML3 at their cross-point (Figs 9c-9d) show correlating reflective bands at the top of the lower crust. Tentatively, we interpret the middle to lower crustal, E-dipping to subhorizontal reflective band at 7.7 to $8.6 \mathrm{~s}$ twt in ML3 as the downward, listric continuation of the upper crustal E-dipping boundary fault. This suggests that the boundary fault has a middle to lower crustal subhorizontal detachment. The reflective lower crust in ML3 correlates with the lower crustal reflective lenses distributed around Horn Graben in ML1. The velocity model of ML1 shows high lower crustal velocities of $6.9-7.2 \mathrm{~km} / \mathrm{s}$ in the northern end of the profile 


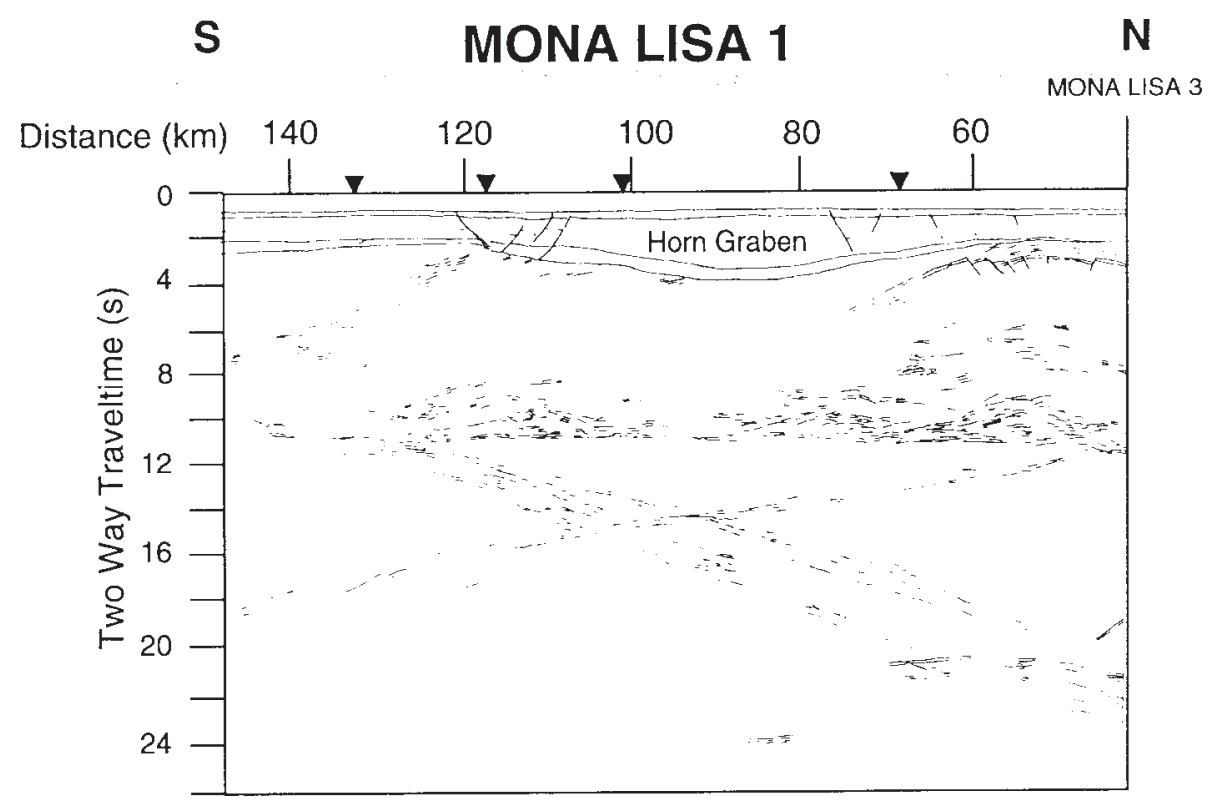

A

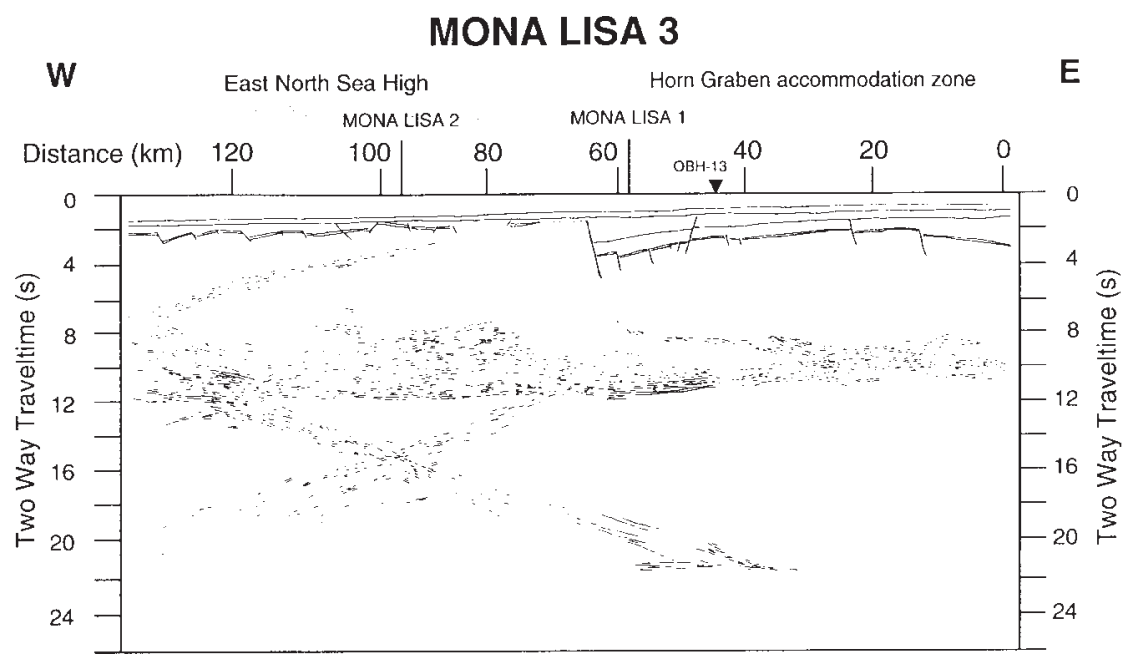

B

(Abramovitz et al. 1998) where there is a pronounced gravity high in the area west of Esbjerg (Klingele et al., 1992). This suggests a correlation between the reflective, high velocity lower crust and the positive Bouguer anomaly as an offshore equivalent to the Silkeborg Gravity High (Thybo \& Schönharting 1991). We interpret these features as evidence for mafic intrusions in the middle and lower crust by magmatic underplating. The origin of these features is probably associated with the Rotliegend volcanic activity in the post-Variscan, Late Carboniferous-Early Permian extensional regime (Thybo \& Schönharting 1991; Thybo 1997).
The sub-Moho structures show two opposing and intersecting bands of reflections from the upper mantle: on ML1 N- and S-dipping mantle reflections and on ML3 E- and W-dipping mantle reflections. The horizontal separation between the Moho offlap of the two bands is $\sim 50$ to $70 \mathrm{~km}$. The N- and E-dipping mantle reflections correlate at the intersection of the two profiles (MONA LISA Working Group 1997). They extend to $20.5 \mathrm{~s}$ twt where they terminate at strong, sub-horizontal reflections at 20.5-21.3 s twt under Horn Graben in both profiles (Fig. 9c). Additionally, the S- and W-dipping mantle reflections correlate between the two profiles (Fig. 9d). They also 


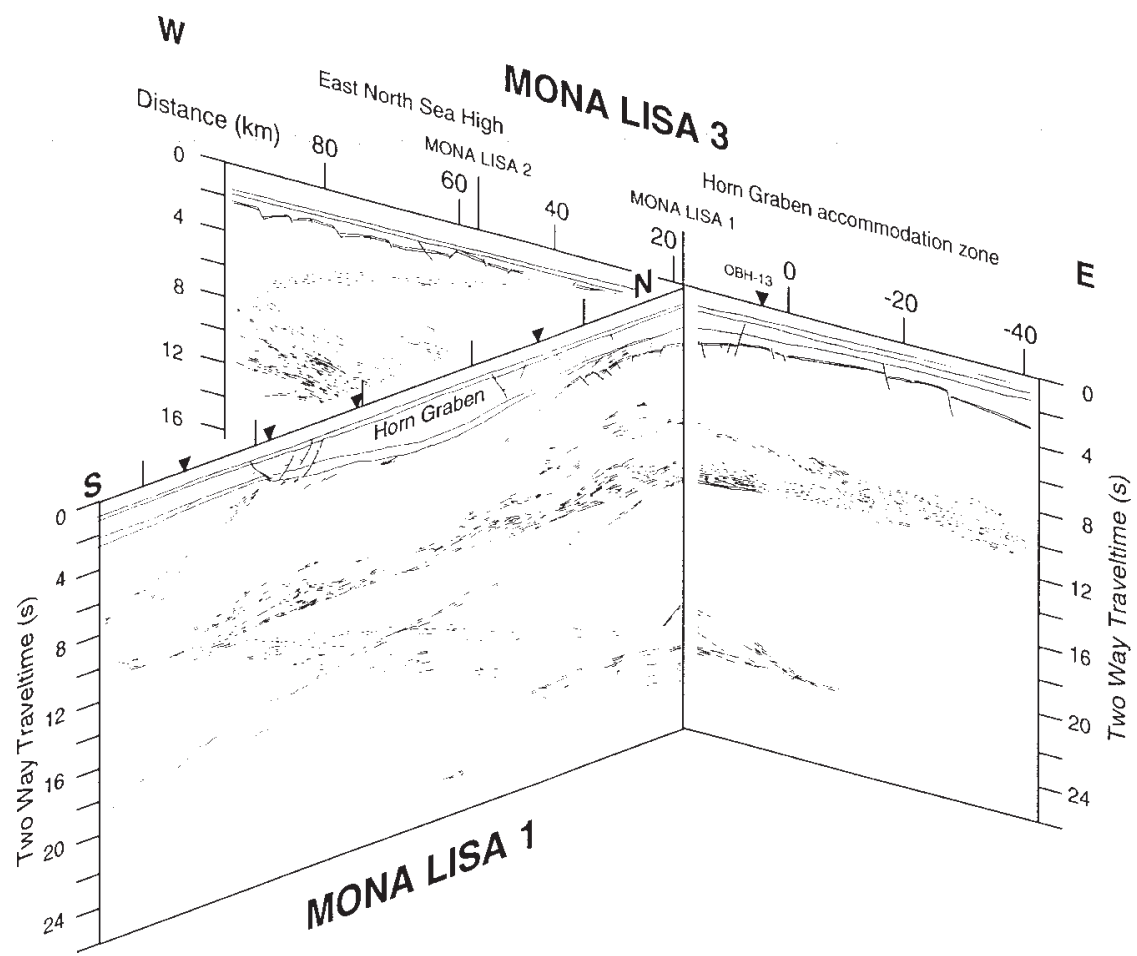

C

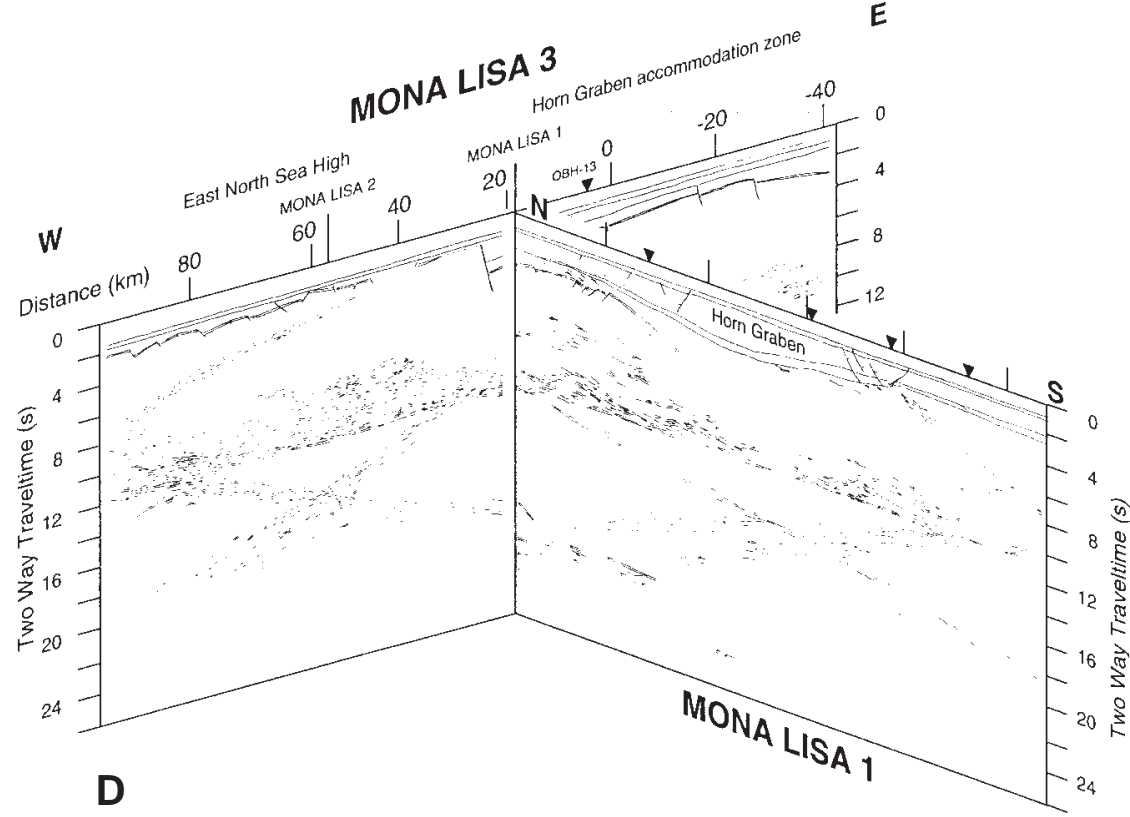

Fig. 9. Line drawings of crustal reflectivity based on the $26 \mathrm{~s}$ twt MONA LISA deep seismic normal-incidence reflection profiles 1 and 3. A) The northern part of ML1. The positions of the ocean bottom hydrophones (OBH) along ML1 are shown by black triangles. Distances refer to the velocity model by Abramovitz et al., 1998. B) The eastern part of ML3. Distances refer to the velocity model shown in Fig. 6. C) Fence diagram showing the correlation between ML1 and ML3 seen from a southeastern direction. Notice the general correspondence in reflectivity from the top basement, lower crust, Moho and upper mantle along the two sub- perpendicular profiles. The correlation of the mantle reflective bands identify a single SW-dipping and a single NE-dipping mantle reflection. D) Fence diagram showing the correlation between ML1 and ML3 seen from a southwestern direction. The distance between the vertical ticks at the top of the ML1 line drawing is $20 \mathrm{~km}$. 


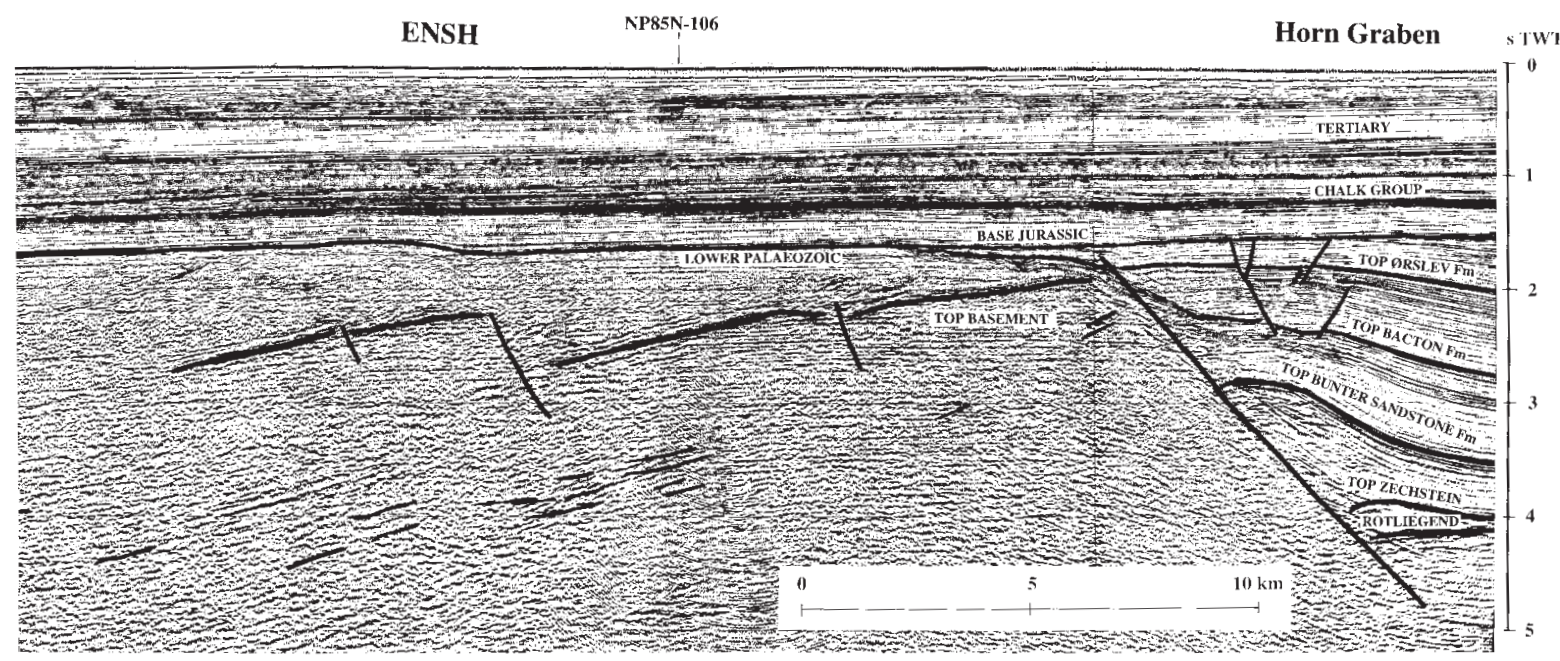

A

W

\section{$\underline{\text { NP85N-014 }}$}

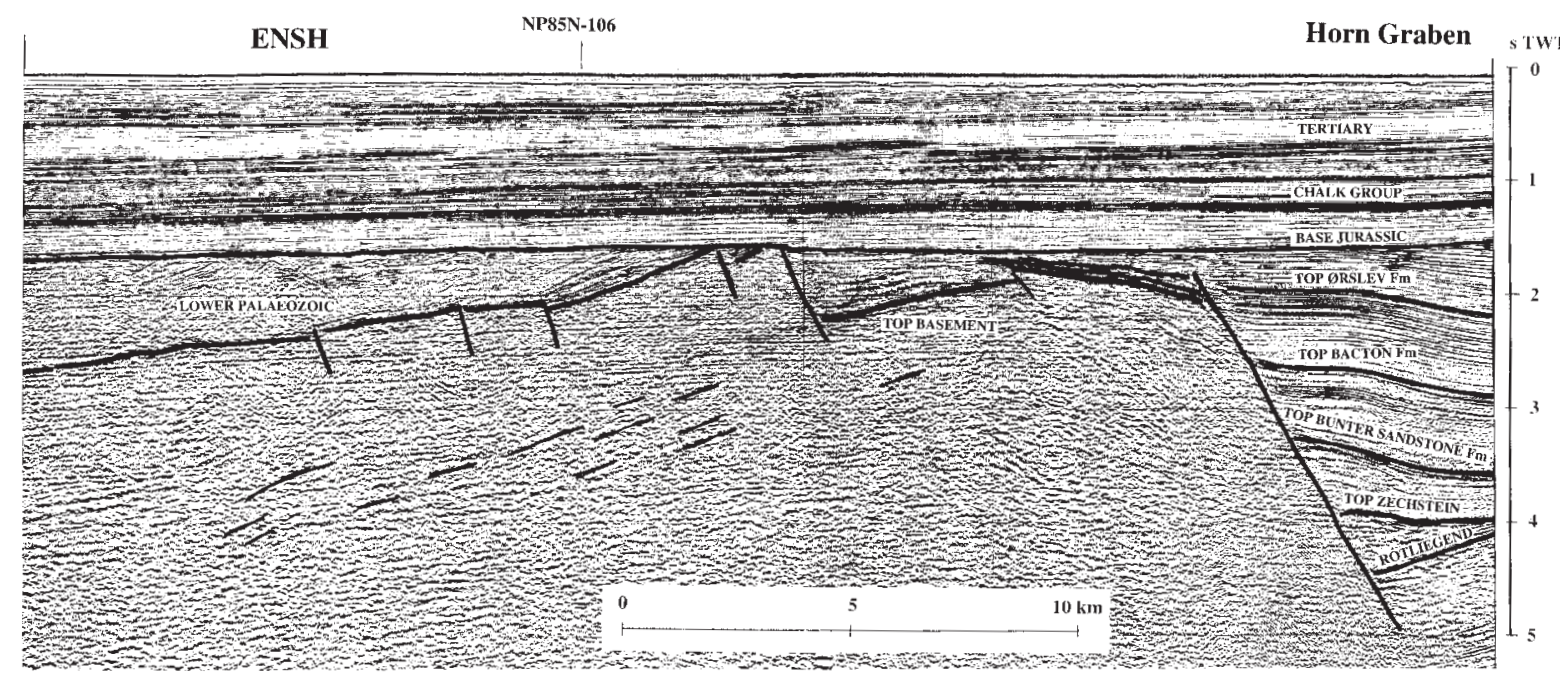

B

continue to deep levels further to the south and west outside the illustrated sections (MONA LISA Working Group 1997). Similar S- and W- dipping mantle reflections are observed on MONA LISA profile 2 and 4 and indicate that a bending mantle reflector exists across the area (Abramovitz \& Thybo, submitted).

\section{Half-grabens in East North Sea High}

Caledonian structures can also be observed in the basement of the East North Sea High, west of Horn Graben. The E-W striking NP85N-013 and -014 profiles and the intersecting N-S striking NP85N-106 profile are all located on the East North Sea High (Figs 2 and 10). The seismic marker horizons have been tied to the nearby S-1 well. The seismic profiles image downfaulted basins, which are unconformably overlain by undifferentiated Jurassic strata to the west of the main Horn Graben boundary fault.

Three SW-dipping half-grabens are imaged above a SW-rotated basement reflector cut by NE-dipping fault planes (Fig. 10). The top basement reflection has the same seismic character as observed on the NP85N025, ML3 and ML1 profiles further to the northeast. Bands of W-dipping reflections at 3 to $4.5 \mathrm{~s} \mathrm{twt} \mathrm{from}$ the crystalline basement on the E-W striking NP85N013 and -014 profiles (Figs 10a-b) match S-dipping 


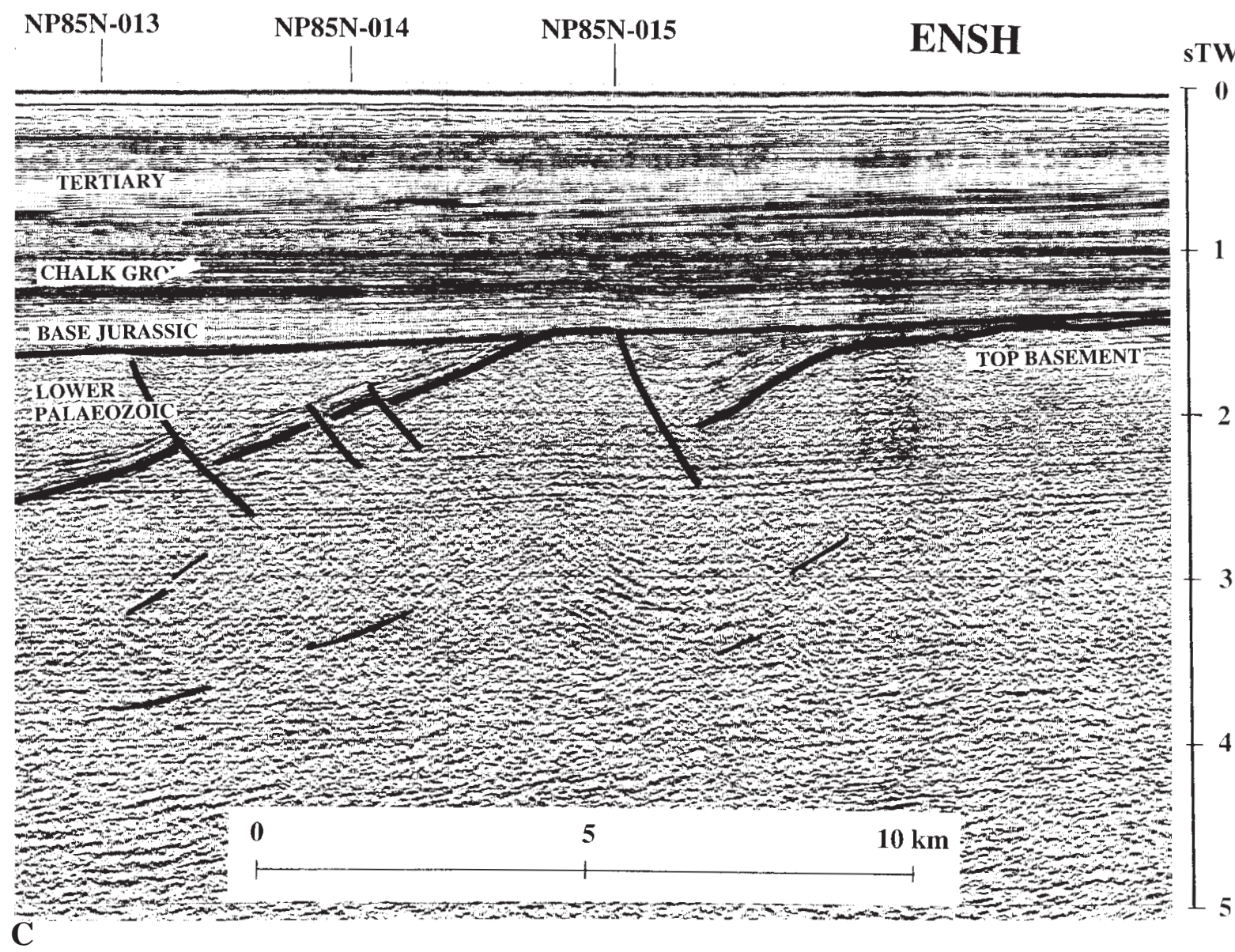

Fig. 10. Examples of down-faulted SW-dipping half-grabens in the crystalline basement of East North Sea High from seismic sections west of Horn Graben. S- and W-dipping reflections are interpreted as Caledonian thrusts. (Tertiary $=$ Cenozoic). A) The time migrated, E-W striking NP85N-013 profile. B) The time migrated, E-W striking NP85N-014 profile. C) The time migrated, N-S striking NP85N-106 profile.

reflections on the N-S striking NP85N-106 profile (Fig. 10c). The reflectivity of the sediments in the SWdipping half-grabens show some resemblance to the pre-rift deposits beneath Horn Graben, even though there is no observable Rotliegend reflector on the basement high (Fig. 3). W- and S-dipping reflections from the lower parts of the sedimentary unit are partly subparallel to the basement reflector (Figs 10a-b). The upper parts are dominated by weak sub-horizontal reflections. On the basis of the reflectivity characteristics, we interpret the sediments in the SW-dipping half-grabens as pre-rift deposits equivalent to those observed beneath Horn Graben. Hence, we ascribe an Early Palaeozoic age to the lower unit with dipping reflections and a Late Palaeozoic age to the upper transparent unit.

Interpretation and modelling of the MONA LISA wide-angle data set from profile 2 indicates an up-to
$2.5 \mathrm{~km}$ thick Palaeozoic sequence with velocities of $4.9-5.6 \mathrm{~km} / \mathrm{s}$ above the crystalline basement of the East North Sea High (Abramovitz \& Thybo, submitted). Zhou and Thybo (1997) interpreted similar occurrences of Palaeozoic sediments from magnetic, gravity and commercial reflection seismic data from the East North Sea High area. The velocity model of MONA LISA profile 2 shows basement velocities of $6.10-6.25 \mathrm{~km} / \mathrm{s}$ at 4 to $5 \mathrm{~km}$ depth in the East North Sea High.

In the eastern parts of the NP85N-013 and -014 profiles, the pre-rift deposits are unconformably overlain by a wedge of Triassic strata (Falster Formation) which thins west- and northward. The western parts are overlain by undifferentiated Jurassic strata below a $\sim 0.3 \mathrm{~s}$ twt thick Chalk Group. The thickness of the Cenozoic strata increases westward from 1.0 to $1.3 \mathrm{~s}$ twt above the East North Sea High. 


\section{Tectonic conclusions}

Integrated studies of normal-incidence reflection data, wide-angle refraction data and other geophysical data (Zhou \& Thybo 1997, Abramovitz et al. 1998, Abramovitz \& Thybo, submitted) reveal substantial occurrences of Palaeozoic strata and preserved Caledonian structures in the southern Horn Graben study area.

\section{Preserved Caledonian structures}

We interpret S- and W-dipping reflections between 2.6 and $4.5 \mathrm{~s} \mathrm{twt} \mathrm{in} \mathrm{the} \mathrm{pre-rift} \mathrm{sequence} \mathrm{in} \mathrm{the} \mathrm{Horn}$ Graben area as preserved Caledonian thrust structures in the upper crustal, frontal part of the Caledonian Deformation Front generated by the collision between Baltica and E. Avalonia. The compressional stress field resulted in faulting, folding and deformation within the Early Palaeozoic Baltica shelf sediments of the foreland basin to the north of the Caledonian orogen. The Caledonian deformed Lower Palaeozoic sediments are now preserved between the Rotliegend and basement reflectors and in intra-basement half-grabens below the sedimentary cover of the East North Sea High. In the Horn Graben area, the Caledonian Deformation Front may be interpreted as a $80 \mathrm{~km}$ wide deformation belt in the Lower Palaeozoic Baltica shelf sediments. The shallow reflections from the upper crustal part of the Caledonian Deformation Front can be correlated with deeper reflections from 3 to $11 \mathrm{~s}$ twt on the N-S striking deep seismic MONA LISA profiles 1 and 2 where they coincide with a southward change in the crustal velocity structure (MONA LISA Working Group 1997; Abramovitz et al. 1998; Abramovitz \& Thybo, submitted). The SW-dipping crustal reflection band is interpreted as mylonitization and shearing along fault planes during tectonic stacking of crustal terranes in the deeper parts of the Caledonian suture zone.

\section{Horn Graben}

Pre-rift deposits are preserved as a up-to $1 \mathrm{~s}$ twt thick sequences beneath the Horn Graben accommodation zone near the intersection of MONA LISA profiles 1 and 3. The average pre-rift deposit thickness appears to increase southwards beneath the graben. The seismic velocity models along MONA LISA profile 1 indicate up-to 3.5-4.1 km of down-faulted Palaeozoic rocks below Horn Graben, which suggests an initial graben of Late Palaeozoic age. Main sedimentary subsidence in the Horn Graben took place during the Triassic, most pronounced in early Triassic times. Vejbæk (1990) ascribes a Triassic age to the main rifting phase with a minor rifting phase in the southern Horn Graben in Rotliegend times as indicated by minor fault offsets at the base Zechstein reflector. We propose that the majority of the pre-rift sequence beneath Horn Graben was deposited in a Caledonian foreland basin on the Baltica plate. The occurrence of Palaeozoic strata in Horn Graben may be interpreted in terms of an initial rifting phase during Late Carboniferous-Early Permian. This is consistent with magnetic features and extensional structures of similar age interpreted by Thybo (1997) in the Tornquist Fan area further east. The uplift of the Mid North SeaRingk $\varnothing$ bing Fyn High probably took place during this episode. As such, we suggest that Horn Graben developed in the original Caledonian foredeep as a graben structure during Late Carboniferous-Early Permian rifting accompanied by magmatic underplating as a result of late-Variscan dextral crustal movements in NW-Europe. The main E-dipping boundary fault in the southern Horn Graben segment appears to be listric at depth with a sub-horizontal detachment at the top of lower crustal, sub-horizontal reflectivity. This reflectivity may originate from mafic intrusions which are simultaneous with the Rotliegend volcanics above the preserved Palaeozoic foredeep sediments.

\section{Dansk sammendrag}

Der er gennemført en tolkning af seismiske refleksionsdata fra Horn Graben området i den syd- $\varnothing$ stlige del af Nordsøen med henblik på en integreret tolkning af de sedimentære strukturer omkring de dybseismiske MONA LISA profiler. De seismiske data viser strukturer fra den kaledoniske kollision mellem Baltica og E. Avalonia, palæozoisk ekstension og magmatisme, samt mesozoisk graben dannelse og sedimentær indsynkning.

I denne sammenhæng fokuserer vi på hældende refleksioner i det krystalline basement og sedimentære strukturer i præ-rift sekvensen mellem Rotliegend og basement reflektorerne i den sydlige del af Horn Graben. Vi har i undersøgelsesområdet kortlagt udbredelsen og to-vejs-tiden (two way traveltime) til Rotliegend reflektoren, som dog ikke er observeret på East North Sea High vest fra Horn Graben. Rotliegend reflektoren udgør en markant strukturel diskordans, idet den afskærer hældende refleksioner fra den underliggende palæozoiske præ-rift serie. Adskillige smă SV-hældende half-grabens med nedforkastede palæozoiske præ-rift aflejringer ses i højderyggen vest for Horn Graben.

Vi tolker hældningen af reflektorerne i præ-rift serien som kaledoniske strukturer dannet ved deformation og foldning i nedre palæozoiske sedimenter aflejret i det kaledoniske fordyb på Baltica pladen nord for selve kollisionszonen. Der er observeret S- og Vhældende refleksioner over $4 \mathrm{~s}$ twt i den sydlige del af Horn Graben ved overgangen til West Schleswig Block samt i det krystalline basement i højderyggen vest for Horn Graben. De tolkes som kaledoniske overskyd- 
ninger i den $\varnothing$ vre del af den SV-hældende Kaledoniske Deformations Front, der kan følges gennnem hele skorpen i de dyb-seismiske MONA LISA sektioner.

Integreret tolkning af refleksionsseismiske strukturer og refraktionsseismiske data viser at der findes betydelige mægtigheder af nedre og $\varnothing$ vre palæozoiske aflejringer i området. Disse aflejringer har størst mægtighed under Horn Graben, hvilket indikerer at denne graben struktur initieredes allerede i Palæozoikum. Den sydlige del af Horn Graben er således udviklet $\mathrm{i}$ det ældre kaledoniske fordyb i forbindelse med sen karbon - tidlig permisk ekstensionstektonik, og dens $\varnothing$-hældende hovedforkastning har et listrisk forløb i den dybe del af skorpen. Forkastningens subhorisontalte udglidningsplan tolkes til at svare til toppen af mafiske intrusioner i mellem og nedre skorpe.

\section{Acknowledgements}

The authors are grateful to A. Berthelsen (University of Copenhagen) for comments to an earlier version of the manuscript. This research received financial support from Maersk Oil and Gas (Copenhagen), the Danish National Science Research Council and the Carlsberg Foundation.

\section{References}

Abramovitz, T., Thybo, H. \& MONA LISA Working Group 1998. Seismic structure across the Caledonian Deformation Front along MONA LISA profile 1 in the southeastern North Sea. Tectonophysics, 288 153-176.

Abramovitz, T. \& Thybo, H., submitted. Seismic images of Caledonian, lithosphere-scale collision structures in the southeastern North Sea along MONA LISA line 2. Submitted to Geophysical Journal International.

Aghabawa, M.A. 1993. Petrology and geochemistry of the Rotliegends volcanic rocks in Denmark and their tectonic implications. DGU kunderapport nr. 35: Dynamisk/ stratigrafisk analyse af Palæozoikum i Danmark. EFP89; Område 1: Olie og naturgas, volume 3, $351 \mathrm{pp.}$

Best, G., Kockel, F. \& Schöneich, H. 1983. Geological history of the southern Horn Graben. In J.P.H. Kaasschieter $\&$ T.J.A. Reijers (eds) Petroleum geology of the southeastern North Sea and the adjacent onshore areas. Geologie en Mijnbouw 62, 25-33.

Brink, H.J., Franke, D., Hoffman, N., Horst, W. \& Oncken, O. 1990. Structure and evolution of the North German Basin. In R. Freeman, P. Giese \& St. Mueller (eds) The European Geotraverse: Integrative studies. European Science Foundation, Strasbourg, 195-212.

Brink, H.J., Dürschner, H. \& Trappe, H. 1992. Some aspects of the late and post-Variscan development of the Northwestern German Basin. Tectonophysics 207, 6595.

Cartwright, J. 1990. The structural evolution of the Ringkøbing-Fyn High. In D.J. Blundell \& A.D. Gibbs (eds) Tectonic evolution of the North Sea Rifts. Publication
No. 181 of the International Lithosphere Programme, Oxford University Press, 200-216.

Clausen, O.R. \& Korstgård, J.A. 1993. Faults and faulting in the Horn Graben area, Danish North Sea. First Break $11,127-143$.

Clausen, O.R. \& Korstgård, J.A. 1994. Displacement geometries along graben bounding faults in the Horn Graben, offshore Denmark. First Break 12, 305-315.

Cocks, L.R.M. \& Fortey, R.A., 1982. Faunal evidence for oceanic separations in the Palaeozoic of Britain. Journal of the Geological Society London, 139, 465-478.

EUGENO-S Working Group 1988. Crustal structure and tectonic evolution of the transition between the Baltic Shield and the North German Caledonides (the EUGENO-S Project). Tectonophysics 150, 253-348.

Frost, R.T.C., Fitch, F.J. \& Miller, J.A. 1981. The age and nature of the crystalline basement of the North Sea Basin. In Illing, L.V. \& Hobson, G.D. (eds) Petroleum Geology of the Continental Shelf of North West Europe, 43-57. Heyden \& Son Ldt. for Institute of Petroleum, London.

Klingele, E., Lahmayer, B. \& Freeman, R., 1992. Bouguer gravity anomalies. In Freeman, R. \& Mueller, St. (eds) A continent revealed: The European Geotraverse project, Atlas of compiled data. 27-31. Cambridge University Press.

Larsen, O. 1971. K/Ar age determinations from the Precambrian of Denmark. Danmarks Geologiske Unders $\varnothing$ gelse, Række 2, 97, 37 pp.

Lie, J.E., Husebye, E.S., Kinck, J.J. \& Larsson, F.R. 1993. Geophysical evidence of Cambrian-Silurian sedimentary rocks in the northern Skagerrak. Geologiska Föreningens i Stockholm Förhandlingar 115, 181-188.

Michelsen, O. \& Nielsen, L.H. 1993. Structural development of the Fennoscandian Border Zone, offshore Denmark. Marine and Petroleum Geology 10, 124-134.

MONA LISA Working Group 1997. MONA LISA - Deep seismic investigations of the lithosphere in the southeastern North Sea. Tectonophysics 269, 1-20.

Poulsen, C. 1969. The Lower Cambrian from Slagelse no. 1, Western Zealand. Danmarks Geologiske Undersøgelse, II Series, 93, 5-29.

Phillips Petroleum Company 1987. Report on potassiumargon age dating and petrological analysis of 3 core plug samples - sample depths: 8525' 5", 8526'2", and 8526'7". Stratigraphic Services International Ltd. (SSL), England.

Sorgenfrei, T. \& Buch, A. 1964. Deep test in Denmark 1935-1959. Danmarks Geologiske Undersøgelse, Række 3, 36, 146 pp.

Thybo, H. \& Schönharting, G. 1991. Geophysical evidence for Early Permian igneous activity in a transtensional environment, Denmark. Tectonophysics 189, 193-208.

Thybo, H. 1997. Geophysical characteristics of the Tornquist Fan area, northwest TESZ: Indications of Late Carboniferous to Early Permian dextral transtension. Geological Magazine 134, 597-606.

Vejbæk, O.V. 1990. The Horn Graben, and its relationship to the Oslo Graben and the Danish Basin. Tectonophysics 178, 29-49.

Vejbæk, O.V. 1997. Dybe strukturer i danske sedimentære bassiner. Geologisk Tidskrift, hæfte 4, 31 pp.

Vejbæk, O.V. \& Britze, P. (eds) 1994. Top pre-Zechstein (twoway traveltime and depth), Geological map of Denmark 1:750000. Danmarks Geologiske Unders $\emptyset$ gelse, Kort serie, 45, 9 pp. 
Zhou, S. \& Thybo, H., 1997. Pre-Zechstein geology of the southeast North Sea, offshore Denmark - A geophyiscal perspective, First Break 15, 387-395.

Ziegler, P.A. 1990. Geological Atlas of Western and Central Europe, 2nd ed. Shell Internationale Petroleum Maatschappij B. V., Elsevier, Amsterdam, 239 pp. 